\title{
Learning from
}

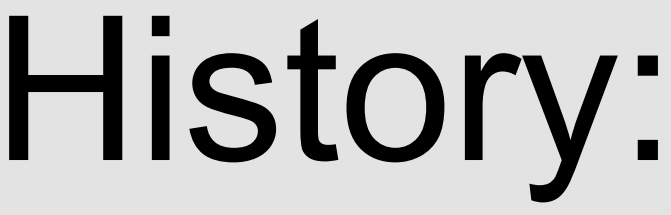

Volatility and

Financial Crises

Jon Danielsson

Marcela Valenzuela

Ilknur Zer

SRC Discussion Paper No 57

February 2016

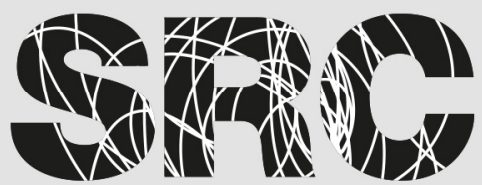




\begin{abstract}
We study the effects of volatility on the probability of financial crises by constructing a cross-country database spanning 211 years. We find that volatility is not a significant predictor of crises whereas unexpected high and low volatilities are. Low volatility leads to banking crises and both high and low volatilities make stock market crises more likely, while volatility in any form has little impact on currency crises. The volatility-crisis relationship becomes stronger when financial markets are more prominent and less regulated. Finally, low-risk environments are conducive to greater buildup of risktaking, providing empirical support for the Minsky hypothesis.
\end{abstract}

Keywords: Stock market volatility, financial crises predictability, volatility paradox, Minsky hypothesis, financial instability, risk taking

JEL Classification: F30, F44, G01, G10, G18, N10, N20

This paper is published as part of the Systemic Risk Centre's Discussion Paper Series. The support of the Economic and Social Research Council (ESRC) in funding the SRC is gratefully acknowledged [grant number ES/K002309/1].

Jon Danielsson, Department of Finance and Systemic Risk Centre, London School of Economics and Political Science

Marcela Valenzuela, University of Chile, DII

Ilknur Zer, Federal Reserve Board

Published by

Systemic Risk Centre

The London School of Economics and Political Science

Houghton Street

London WC2A 2AE

All rights reserved. No part of this publication may be reproduced, stored in a retrieval system or transmitted in any form or by any means without the prior permission in writing of the publisher nor be issued to the public or circulated in any form other than that in which it is published.

Requests for permission to reproduce any article or part of the Working Paper should be sent to the editor at the above address.

(C) Jon Danielsson, Marcela Valenzuela and Ilknur Zer submitted 2016 


\title{
Learning from History: Volatility and Financial Crises*
}

\author{
Jon Danielsson \\ Systemic Risk Centre \\ London School of Economics
}

\author{
Marcela Valenzuela \\ University of Chile, DII
}

\author{
Ilknur Zer \\ Federal Reserve Board
}

December 2015

\begin{abstract}
We study the effects of volatility on the probability of financial crises by constructing a cross-country database spanning 211 years. We find that volatility is not a significant predictor of crises whereas unexpected high and low volatilities are. Low volatility leads to banking crises and both high and low volatilities make stock market crises more likely, while volatility in any form has little impact on currency crises. The volatility-crisis relationship becomes stronger when financial markets are more prominent and less regulated. Finally, low-risk environments are conducive to greater buildup of risk-taking, providing empirical support for the Minsky hypothesis.
\end{abstract}

Keywords: Stock market volatility, financial crises predictability, volatility paradox, Minsky hypothesis, financial instability, risk taking

JEL classification: F30, F44, G01, G10, G18, N10, N20

\footnotetext{
*Corresponding author Jon Danielsson, Department of Finance and the Systemic Risk Centre, London School of Economics, London WC2A 2AE, UK. j.danielsson@lse.ac.uk, +44 2079556056. Updated versions of this paper can be found on www.RiskResearch.org and the Webappendix for the paper is at www.ModelsandRisk.org/volatility-and-crises. We thank Gazi Kara, Adriana Linares, Robert Macrae, Rene Stulz, Jean-Pierre Zigrand, and seminar participants at the Federal Reserve Board and San Fransisco FED. Valenzuela acknowledges the support of Fondecyt Project No. 11140541 and Instituto Milenio ICM IS130002. We thank the Economic and Social Research Council (UK) [grant number: ES/K002309/1] for its support. The views in this paper are solely those of the authors and should not be interpreted as reflecting the views of the Board of Governors of the Federal Reserve System or of any other person associated with the Federal Reserve System.
} 


\section{Introduction}

"Volatility, both actual and expected, in markets is at low levels... to the extent that low levels of volatility may induce risk-taking behavior ... is a concern to me and to the Committee."

Federal Reserve Chair Janet Yellen, June 18, 2014.

Does unexpected financial market volatility imply an increased likelihood of a subsequent financial crisis? A common view maintains it does, pointing to the low volatility in the United States in the years prior to the 2008 crisis. This view is backed up by the theoretical literature, which finds clear channels for how volatility affects the likelihood of crises. However, to the best of our knowledge, it has not been conclusively empirically studied, which motivates our empirical investigation into the link between financial market volatility, the real economy, and crises.

Market volatility is of clear interest to policymakers, with the above quotation by Chair Yellen just one example. Within the post-crisis macroprudential agenda, policymakers are actively searching for signals of future financial and economic instability and developing policy tools to mitigate the most unfortunate outcomes. Volatility is a part of the macro-prudential toolkit. Unfortunately, in the absence of clear empirical guidance as to how volatility affects future crises, it can be a difficult tool to wield.

Concerns about the relationship between the financial market and economic risk have a long history in the economic literature, notably Keynes (1936), Hayek (1960), and Minsky (1992) who argue that economic agents change their risk-taking behavior when they perceive that financial market risk is not what they have come to expect.

Thus, the theoretical literature suggests that financial market volatility affects economic decisions, especially when it deviates from what economic agents have come to expect it to be. Higher-than-expected levels of volatility indicate higher uncertainty regarding future cash flows and discount rates, and hence, future economic conditions. Such unexpectedly high volatility can therefore be seen by forward-looking economic agents as a signal of the increased risk of adverse future outcomes and a pending crisis. We term this chain of events the high volatility channel.

Unexpectedly low volatility may also lead to a crisis, via what we denote the low volatility channel. Danielsson et al. (2012) propose a general equilibrium framework, whereby low 
risk induces economic agents to take more risk, which then endogenously affects the likelihood of future shocks. Similarly, Brunnermeier and Sannikov (2014), studying the volatility paradox, model how low fundamental risk leads to higher equilibrium leverage and hence the buildup of systemic risk.

These arguments suggest that the high volatility channel is most important closer to a crisis, while the low channel is most important farther from a crisis. Low volatility induces risk-taking, which only materializes during a crisis, while high volatility is a signal of a pending crisis.

That leaves the question of how to quantify unexpected levels of volatility. Our empirical evidence indicates that volatility exhibits a slow-moving, non-linear trend. Borrowing terminology from the literature on output gap, we interpret this slow-run trend as longterm expected volatility and calculate it using a one-sided Hodrick and Prescott (1997) filter. Unexpected high and low volatility (or high and low volatility in short) are then deviations of volatility from above and below its trend, respectively. This implies four different notions of volatility: the level of volatility, expected volatility, and high and low volatilities.

Several authors have examined the relationship between volatility and recessions and patterns in volatility during crises, almost exclusively focusing on the United States. ${ }^{1}$ However, to the best of our knowledge we are the first to formally examine how volatility may predict financial crises. While we do not know why the literature has not addressed the issue, we can advance two hypotheses. First, the presence of two simultaneous volatility channels is likely to frustrate empirical analysis solely focusing on volatility. Second, as we argue below, it is helpful to make use of long historical relationships.

In an empirical exploration of the connection between volatility and crises we face two paths. We could focus on recent history with daily market activity measurements and ample economic and financial statistics. However, this would limit us to data from the past few decades at best. Since crises are rare events, the resulting sample size would be inevitably small. For instance, an OECD member country suffers a banking crisis every 35 years, on average. Alternatively, we could exploit long-term historical relationships over multiple decades and centuries, but at the expense of more limited data. We opted

\footnotetext{
${ }^{1}$ See for example, Schwert $(1989,1990)$; Hamilton and Lin (1996); Fornari and Mele (2009); Corradi et al. (2013)
} 
for the long-term historical view believing it to be the best way to obtain meaningful relationships between volatility and crises.

We construct a database on historical volatilities from primary sources, collecting monthly stock market returns from which we obtain annual volatility estimates. The sample covers 60 countries and spans 211 years, resulting in about 3,500 country-year observations. On average, the database covers 62 years of historical observations per country.

We consider three varieties of financial crises: banking, stock market, and currency, adopting the data set of Reinhart and Rogoff (2009). The end result is an unbalanced panel that contains a binary indicator of whether a financial crisis occurs in a given year and country. The coverage is fairly comprehensive, with 262 banking crises, 419 stock market crises, and 540 currency crises.

We obtain a number of results on the relationship between volatility, the macroeconomy, and crises, providing new insights while also being consistent with the extant theoretical literature. We are not aware of any empirical papers documenting most of these phenomena.

First, the level of volatility does not predict financial crises, but unexpectedly high and low volatilities do. The impact depends on the crisis type. For stock market crises, both high and low volatility are important. For banking crises, low volatility dominates. Finally for currency crisis, volatility does not have an impact in most cases. These results are robust to a range of tests based on alternative model specifications and definitions of volatility.

Second, low volatility predicts stock market crises that happen half a decade or more into the future, while high volatility predicts crises that happen in the next 2 to 5 years. We also find that low volatility Granger causes high volatility, but not vice versa, further supporting the view that persistently low volatility for a prolonged period of time leads to a crisis, while higher volatility signals a pending crisis.

Third, we formally verify that the unexpected volatility-financial crises link also holds out-of-sample. In addition, using high and low volatility as crisis indicators delivers a strong signal-to-noise ratio, significantly beating random noise.

Fourth, since our 211-year sample contains a variety of economic systems and market structures, currency regimes and technological developments, it is of interest to examine the volatility-crisis relationship over key sub-periods of the sample. The relationship 
between financial market volatility and the incidence of a crisis becomes stronger over time - not surprising considering that prior to World War I, stock markets played a much smaller role in the economy than they would later. The relationship weakened again during the Bretton Woods era when financial markets and capital flows were heavily regulated.

In our last set of results, we empirically confirm the theoretical prediction that low volatility induces risk-taking, defined by commonly used proxies for financial intermediaries. This result is consistent with Minsky's instability hypothesis, Brunnermeier and Sannikov's (2014) volatility paradox, and the endogenous risk of Danielsson et al. (2012).

Taken together, we find unambiguous support for how volatility relates to the incidence of financial crisis. In particular, the high and low volatility channels are significant above and beyond the level of volatility, where low volatility leads to risk-taking that ultimately culminates in high volatility and crises. The relationship becomes stronger when financial markets are more prominent and less regulated.

These results should be of value to macroprudential and monetary policymakers, as they provide clear guidance for how one should think about the relationship between financial market risk and the macroeconomy. By identifying the channels by which volatility affects the incidence of crises, policymakers are able to better understand the links between the two. Hence, they may want to consider including high and low volatilities in their set of crisis indicators, which would lead to more robust policy tools dealing with financial stability and systemic events.

The rest of the paper is organized as follows. In Section 2, we explain the high and low volatility channels and their possible relationship with financial crises in detail, along with the related literature. In Section 3, we describe the construction of the database and the method to decompose volatility. In Sections 4 and 5, we present the econometric methodology and the main results, respectively. In Section 6, we examine whether low volatility leads to an increase in risk-taking behavior. Finally, Section 7 concludes.

\section{Background and related literature}

Financial market risk directly affects the real economy because of its role in the financing of economic projects and its impact on agents' expectations. Not surprisingly, there is a 
long line of research documenting such links, be it from theoretical, empirical or policy directions.

The early theoretical literature identifies high and low volatility channels as contributors to financial crises. Traditional finance theory associates high volatility with uncertainty about future investment payoffs and hence, uncertainty about the relevant macroeconomic variables, such as investment and consumption. For instance, Keynes (1936) argues that the amount of investment is a key factor in economic performance, where investment is affected by risk. The modern literature reaches similar conclusions. The real options literature emphasizes that if the volatility of future payoffs increases, the value of an option to invest increases, delaying investment (Dixit and Pindyck, 1994). In this view, high volatility may lead to adverse outcomes or crises, via what we call the high volatility channel.

Moreover, the financial authorities focus on the high volatility channel in both macroprudential and microprudential regulations, using high volatility as an indication of a pending crisis. That motivates official intervention where banks are required to reduce their risk-taking or increase capital.

The link between the unexpectedly low volatility and the probability of a future crisis, via what we name the low volatility channel, is also emphasized in the theoretical literature. Hayek (1960) observes the presence of a risk cycle as separate from the business cycle, whereby low risk encourages risk-taking. Minsky's (1992) instability hypothesis suggests that economic agents interpret the presence of a low risk environment as an incentive to increase risk-taking, which in turn may lead to a crisis (Schularick and Taylor, 2012; Ranciere et al., 2015). That would create a channel for low volatility to endogenously increase the probability of market turmoil and an eventual crisis.

In a recent paper, Brunnermeier and Sannikov (2014) identify what they term the "volatility paradox" where low risk can paradoxically increase the probability of a systemic event. Similarly, Danielsson et al. (2012) use a general equilibrium framework to analyze how perceptions of risk affect investors' risk-taking and the perception of volatility, where even small changes in volatility can lead to rapid price movements associated with crises and endogenously affect volatility. Bhattacharya et al. (2015) model Minsky's (1992) hypothesis formally with the possibility of endogenous default, where agents update their expectations during good times and increase their leverage. 
One possible link between low volatility and crises is related to the risk-taking behavior of asset managers. Expectations of low risk may encourage asset managers to reach for yield by investing large positions in riskier asset classes. Similarly, risk measures, such as Value-at-Risk or Sharpe ratios, are commonly used by risk managers of financial institutions to control the risk-taking of traders where for a given risk threshold, lower volatility allows a trader to take more risky positions.

In contrast to the theoretical analysis, it has proven harder to empirically examine the relationship between financial market volatility, the real economy, and crises, giving rise to Paul Samuelson's famous 1966 quip "Wall Street indexes predicted nine out of the last five recessions!" The empirical literature examining the financial volatilitycrises relationship generally focuses on 20th century United States data and finds that recessions or financial crises are associated with high volatility (see, for instance, Schwert, 1989, 1990; Hamilton and Lin, 1996; Fornari and Mele, 2009; Corradi et al., 2013).

This paper is also part of the vast empirical literature that studies the determinants of crises. A prominent early example is Demirguc-Kunt and Detragianhe (1998), who consider the factors affecting the probability of banking crises for 65 countries for the period of 1980 to 1994. By constructing a data set of banking and currency crises spanning 120 years, Bordo et al. (2001) document that capital controls affect the probability of a crisis. More recently, several authors have made use of the Reinhart and Rogoff (2009) database, including Reinhart and Rogoff (2011), who focus on banking crises and relevant variables affecting their likelihood. More recent studies along similar lines are Gourinchas and Obstfeld (2012); Jorda et al. (2010); Schularick and Taylor (2012).

The main contribution of this paper is the identification of unexpected volatility, but not the level of volatility, as a strong predictor of financial crises. Our empirical results provide support for theoretical predictions by demonstrating the presence of high and low volatility channels and reinforce the existing literature on the determinants of crises. We also demonstrate that persistently low volatility over a prolonged period leads to higher risk-taking, supporting Minsky's hypothesis. Finally, we contribute to the literature that examines the nature of financial crises with new panel data sets by we constructing a cross-country volatility data set spanning over 200 years. 


\section{$3 \quad$ Modeling volatility}

Our question of interest is whether volatility predicts crises, using historically long and comprehensive volatility observations. We are aware of no database on historical volatility, but fortunately, it is possible to construct such a database by using existing data on stock market returns. Still, the coverage of the stock market data are not quite as wide-ranging as for crises. A country might not have an organized stock market for some part of its history or historians may not have reconstructed stock market indices from primary sources. Fortunately, we are able to construct volatilities for 60 countries, some dating back to 1800, using monthly stock market indices collected by ww. globalfinancialdata.com.

In what follows, we demonstrate the volatility modeling process by showing data from the United States, while the Web appendix, www.ModelsandRisk.org/volatilityand-crises, contains similar analyses for every country in the sample.

\subsection{Volatility construction}

We measure annual volatility by the standard deviation of 12 monthly returns. ${ }^{2}$ Ideally, one might need to use daily return observations to catch important high frequency information. However, such observations on financial markets are scarce. While we can go to the early 20th century for the United States, daily data for most, if not all, of the other countries only extend from the second part of the 20th century. Moreover, we are interested in the effects of volatility on financial crises, where the latter is measured at the annual frequency. Hence, monthly stock market returns are sufficient.

Since many of the countries in the sample have experienced high inflation at times, it is necessary to adjust the stock market data for inflation, for which we use the consumer price index (CPI). For cases in which only quarterly, not monthly, CPI is available, we interpolated the quarterly CPI to the monthly CPI. This interpolation should not be problematic because the CPI moves much more slowly than the stock markets and therefore any interpolation error would only marginally affect the volatility.

\footnotetext{
${ }^{2}$ We also estimate annual volatility as the sum of the absolute value of real returns, yielding qualitatively similar results as discussed in Section 5.5.
} 
Not surprisingly, in such a comprehensive sample of stock market returns, a number of extreme observations occur, generally due to disruptive events like war and hyperinflationary periods. In such cases, the unconditional volatility is likely to be biased, as discussed by Muler and Yohai (2008), for whom it is preferable to use robust estimators of volatility by bounding extreme observations. Hence, similar to Han (2013) and Wahal and Yavuz (2013), we winsorize 1\% of monthly real returns for each country separately, prior to the estimation of volatility. ${ }^{3}$

Figure 1 shows the time-series plot of the monthly real returns, winsorization and the resulting annual volatility. The figure shows that there are few episodes when winsorization is applied, all corresponding to wars or major crises, like the Civil War, the Great Depression, and the 1908, 1987, and 2008 crises.

\section{Figure 1: Return and volatility estimates for the United States}

Monthly real stock market returns (adjusted with CPI), winsorized real returns at the $1 \%$ level and volatility estimates for the United States. Volatility is calculated as the standard deviation of 12 winsorized monthly real returns.

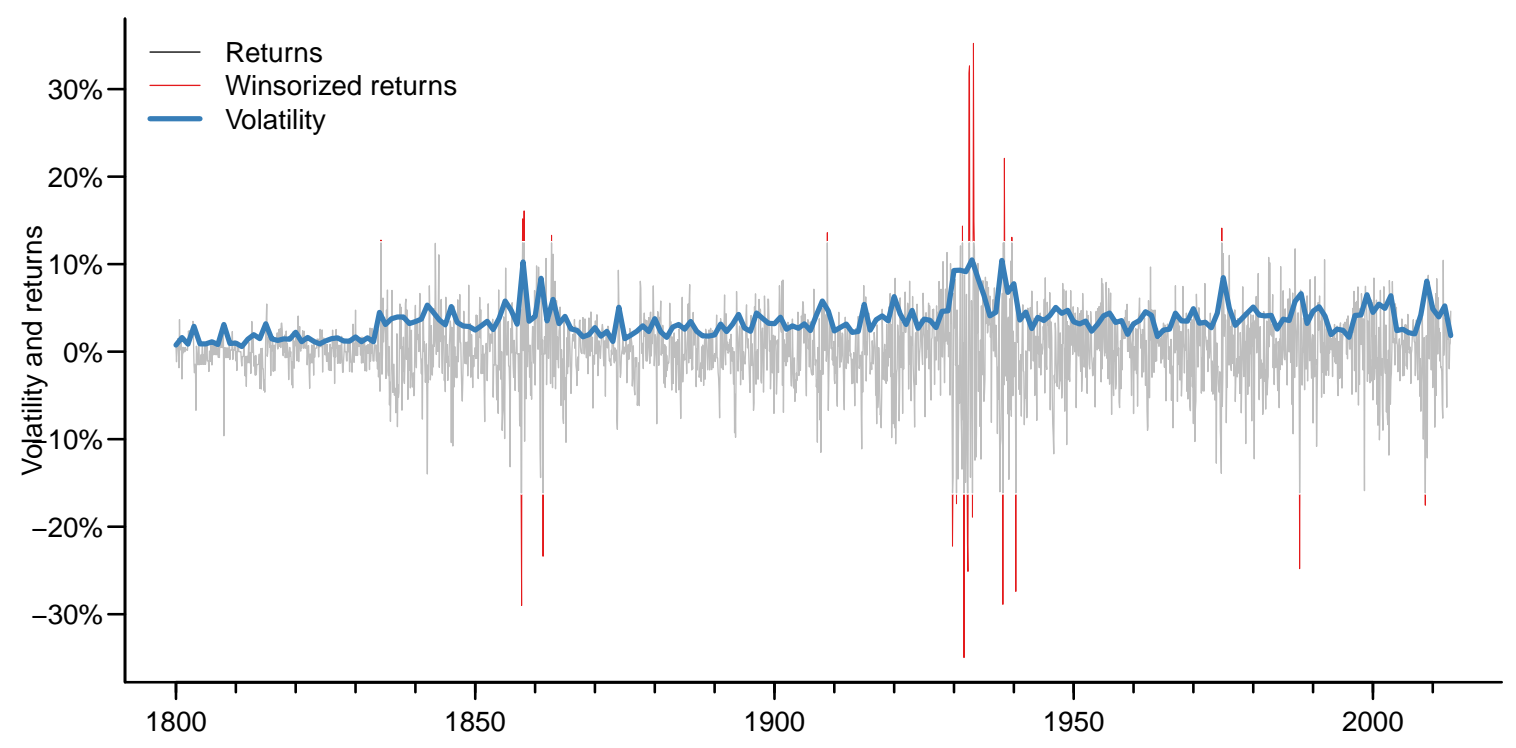

\footnotetext{
${ }^{3}$ More specifically, if a given country's real monthly return is above its 99.5 th percentile, we set the return as the top 99.5th percentile value. Real returns below the 0.5 th percentile are winsorized analogously. Results are robust to non-winsorization and winsorization at the $5 \%$ level.
} 


\subsection{Descriptive analysis: Volatility}

Figure 2 shows the volatility for each country in the sample, as their data become available. Only data for the United States and Great Britain are available from 1800, while data for France, Germany, and Australia become available from the mid-19th century. However, a large number of countries only developed stock markets after World War I. The figure further shows that emerging countries have more volatile stock markets than developed countries. Indeed, we find that the annual stock market volatility of emerging countries averages $23 \%$, compared to $16 \%$ for developed countries.

Figure 2: Time-series plot of volatilities for developed and emerging countries

The annual volatility level, $\sigma_{t}$, calculated as the standard deviation of the previous 12 winsorized monthly real returns scaled by $\sqrt{12}$, for all of the countries in our sample, as their data become available. The estimates for the developed and emerging countries are labeled with different colors, where the classifications are adopted from the IMF definition. The sample spans 1800-2010 and includes 60 countries.

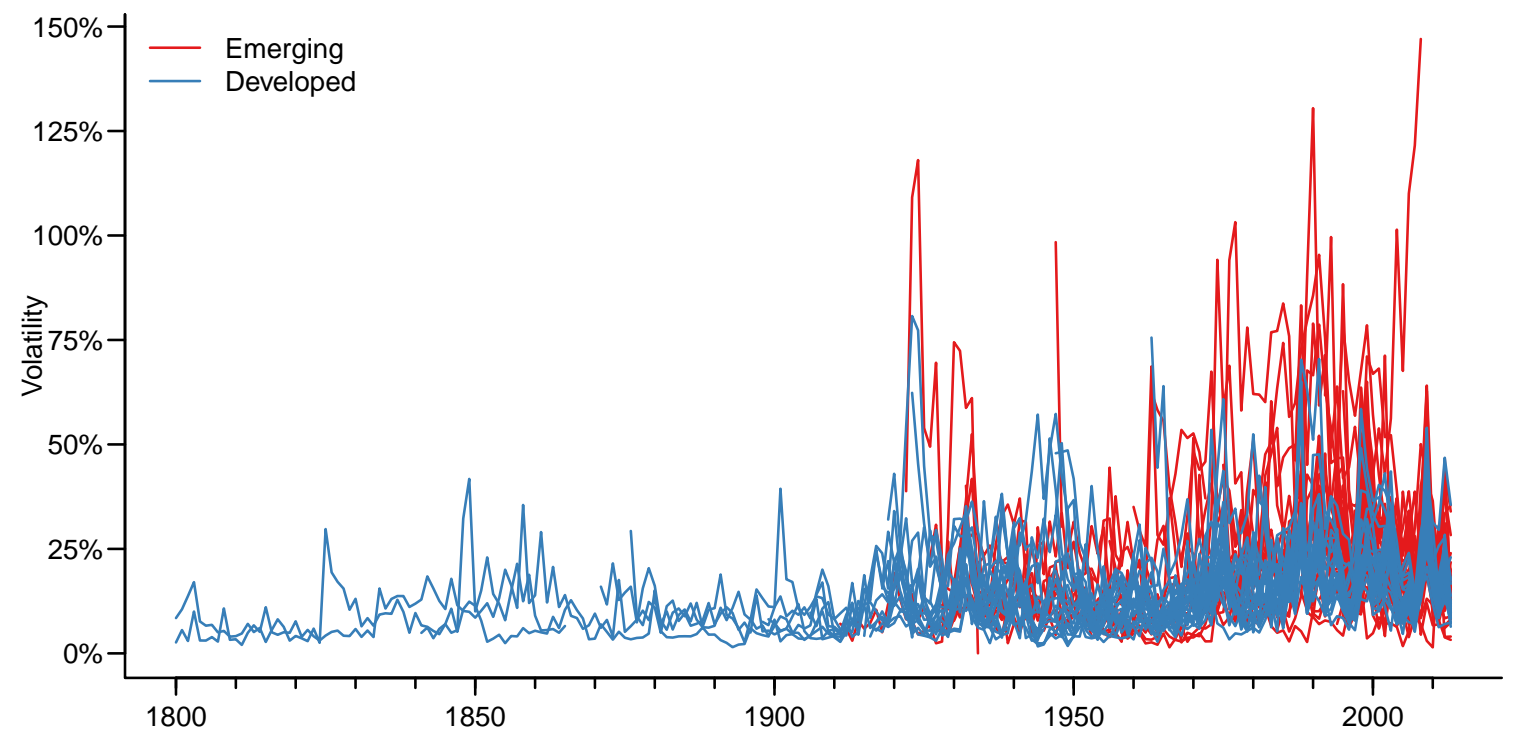

A similar picture emerges from Figure 3, which shows the average volatility for subperiods of the data, segmented by emerging and developed countries. Although there are many interesting sub-periods within the sample that merit special attention, to keep the discussion tractable, we opt to focus on five of the most interesting: the pre-gold period (1800-1872), the gold standard era (1873-1913), the interwar years (1919-1938), and finally the so-called Great Moderation (the two decades before the 2008 crisis). 
Within the periods we consider, financial volatility is the highest during the 1985-2006 period, with the interwar years not far behind. This is interesting as the years of the Great Moderation tend to be associated with the lowest macroeconomic volatility, at least for developed countries (see e.g. Blanchard and Simon, 2001; Bernanke, 2012). One source of high volatility during the Great Moderation for emerging countries is the multiple crises suffered by some Asian and Latin American countries during that period.

\section{Figure 3: Volatility levels-sub-periods}

Average volatility levels for sub-periods for developed and emerging countries separately. The pre-gold (1800-1872), gold (1873-1913), interwar (1919-1938), Bretton Woods (1949-1972), and Great Moderation (1985-2006) periods as well as the whole sample period (1800-2010), are considered. Volatility is calculated as the standard deviation of the previous 12 winsorized monthly real returns, scaled by $\sqrt{12}$, and the sample includes 60 countries. Emerging and developed countries' classifications are adopted from the IMF definition.

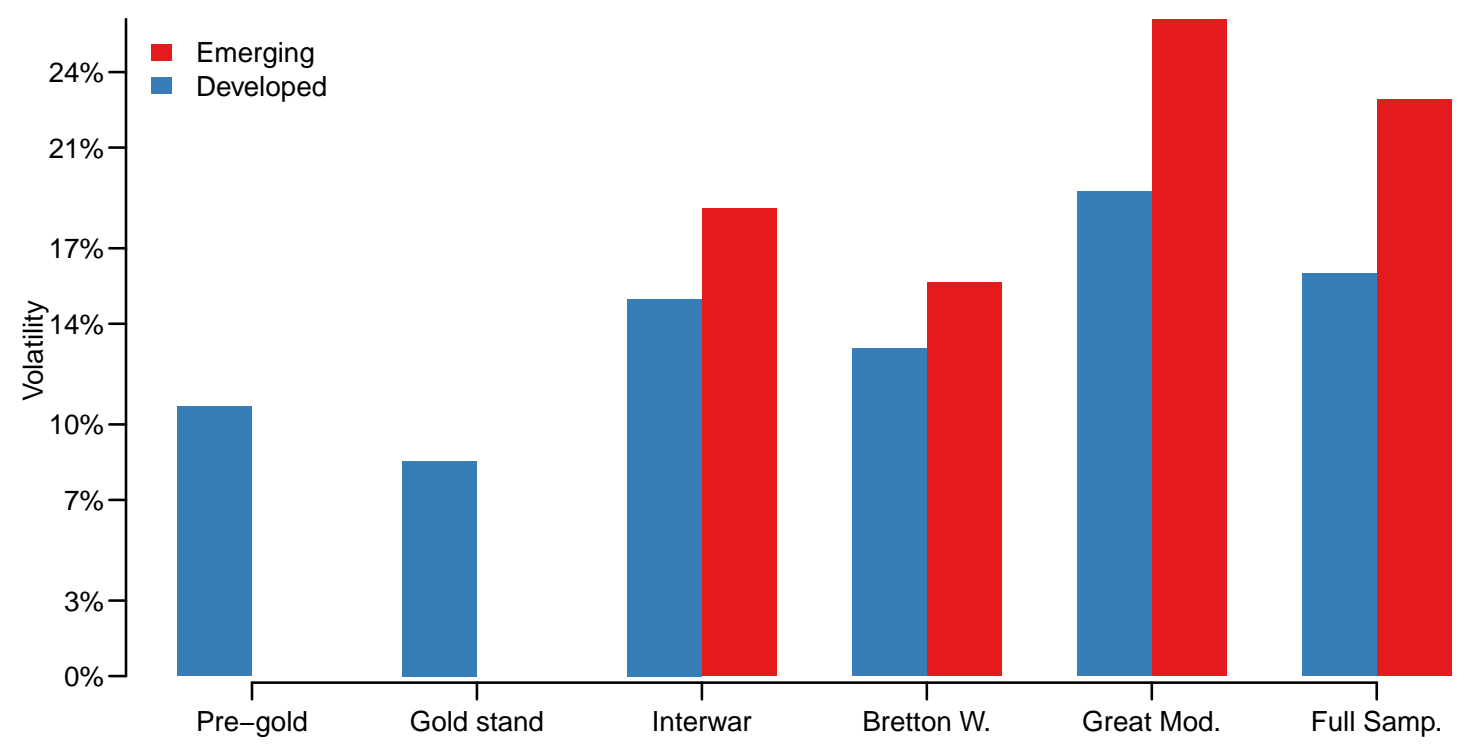

These results are augmented by Figure 4, which shows the correlations between monthly real returns for developed and emerging countries. We see that within our 211 years of history, stock markets have always been quite related to each other.

In the earliest period, we only have a handful of countries, and even though there was no electronic communication between countries or across the Atlantic, the stock market correlations still exceeded 15\%. The correlations are lowest during the Bretton Woods era, when capital controls were in widespread use, limiting cross-border investment. If one uses correlations as a proxy for how financial markets are integrated with each other, these results suggest that market integration is in part driven by regulations. Since then, correlations have increased sharply. Indeed, the highest correlations are recorded during 
the last part of the sample (after 2007). Finally, although emerging countries have quite a low level of correlation between them, their returns are, as expected, highly correlated with those of the United States.

\section{Figure 4: Correlations}

The average monthly return correlations of all, developed and emerging countries, separately. The average correlation between the emerging countries' and the United States' returns are also presented. We first calculate the bilateral correlations between the countries with available data for a given period. We then report the cross-sectional averages. The pre-gold (1800-1872), gold (1873-1913), interwar (1919-1938), Bretton Woods (1949-1972), and Great Moderation (1985-2006) periods, as well as the whole sample period (1800-2010), are considered. The sample includes 60 countries. Emerging and developed countries' classifications are adopted from the IMF definition.

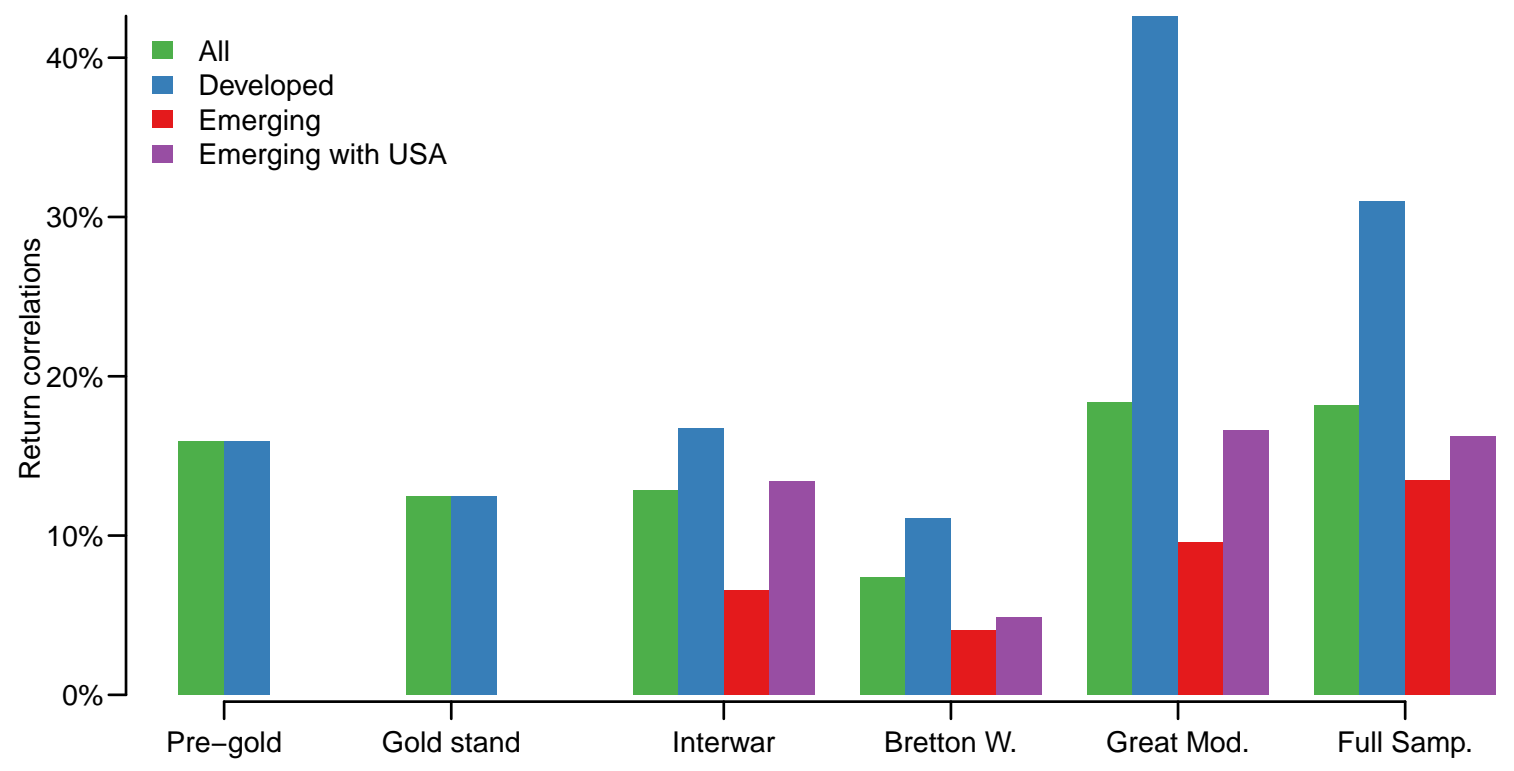

\subsection{Decomposing volatility}

Our main question of interest is whether the high and low volatility channels are significant determinants of the incidence of a financial crisis. Hence, we need a methodology to identify these channels.

Figure 5 suggests the presence of a slow-moving, non-monotone trend spanning multiple decades, with two main peaks, corresponding to the Civil War and the Great Depression. The expected level of volatility in the 1860 s is around $20 \%$, dropping to about $7 \%$ in the 1890 s, increasing to $27 \%$ during the interwar period, and decreasing back to $8 \%$ in the 1960s. Similar patterns exist for other countries. 
Furthermore, the level of volatility differs considerably across countries at any given time. These two combined effects - the presence of a slow-moving trend and heterogeneous volatility levels - have the potential to frustrate empirical analysis. The reason is that a particular measurement of volatility could be seen as high, low, or typical depending on the country or year.

We address this problem by decomposing volatility $(\sigma)$ with the Hodrick and Prescott (1997) (HP) filter into trend $(\tau)$ and deviation from trend $(\delta)$, in different contexts referred to as cycle.

$$
\sigma_{t}=\tau_{t}(\lambda)+\delta_{t}(\lambda), \quad t=1,2, \ldots, T
$$

where $\lambda$ denotes the smoothing parameter, which quantifies the degree to which volatility is trend. The higher the $\lambda$, the smoother the trend and hence, the closer $\delta$ is to $\sigma$.

The standard two-sided HP filter uses the entire sample to construct the filter at time $t$. This means that information that is unavailable when macroprudential policy decisions are actually made is used to construct the trend. Therefore, it is more realistic to use the one-sided filter; i.e., to run the standard HP filter recursively through time by using only data available up to year $t$, estimate the trend and retain the final value as the trend for year $t$. This recursive setting assumes that only current and past states influence the current observation.

In order to identify the high and low volatility channels, we further separate the deviation of volatility from its trend into two components. We use the terms high volatility $\left(\delta^{\text {high }}\right)$ and low volatility $\left(\delta^{\text {low }}\right)$ to indicate these two cases.

$$
\begin{aligned}
\delta_{\mathrm{t}}^{\text {high }}(\lambda) & =\left\{\begin{array}{lll}
\sigma_{t}-\tau_{t}(\lambda) & \text { if } & \sigma_{t} \geq \tau_{t}(\lambda) \\
0 & \text { otherwise, }
\end{array}\right. \\
\delta_{\mathrm{t}}^{\text {low }}(\lambda) & = \begin{cases}\left|\sigma_{t}-\tau_{t}(\lambda)\right| & \text { if } \\
0 & \text { otherwise. }\end{cases}
\end{aligned}
$$

Note that we use absolute value of low volatility in regressions to ease the interpretation of the estimated coefficients.

Figure 5 visualizes the volatility, trend, and high and low components of volatility for $\lambda=5000$. Panel (a) shows the volatility level $\left(\sigma_{t}\right)$ and estimated trend $\left(\tau_{t}\right)$, marking the 


\section{Figure 5: Estimated trend and high and low volatility, United States}

Annual volatility level $\left(\sigma_{t}\right)$ and estimated trend $\left(\tau_{t}\right)$ for the United States. Volatility is calculated as the standard deviation of the previous 12 winsorized monthly real returns scaled by $\sqrt{12}$. Then, the Hodrick and Prescott (1997) filter is applied to decompose volatility level into trend and deviations from the trend. In Panel (a), we mark the areas of volatility where it is both above and below the trend. In Panel (b), we plot high and low volatility- $\delta_{t}^{\text {high }}$ and $\delta_{t}^{\text {low }}$ - introduced in (2). The pre-gold (1800-1872), gold (1873-1913), interwar (1919-1938), Bretton Woods (1949-1972), and Great Moderation (1985-2006) periods are highlighted.

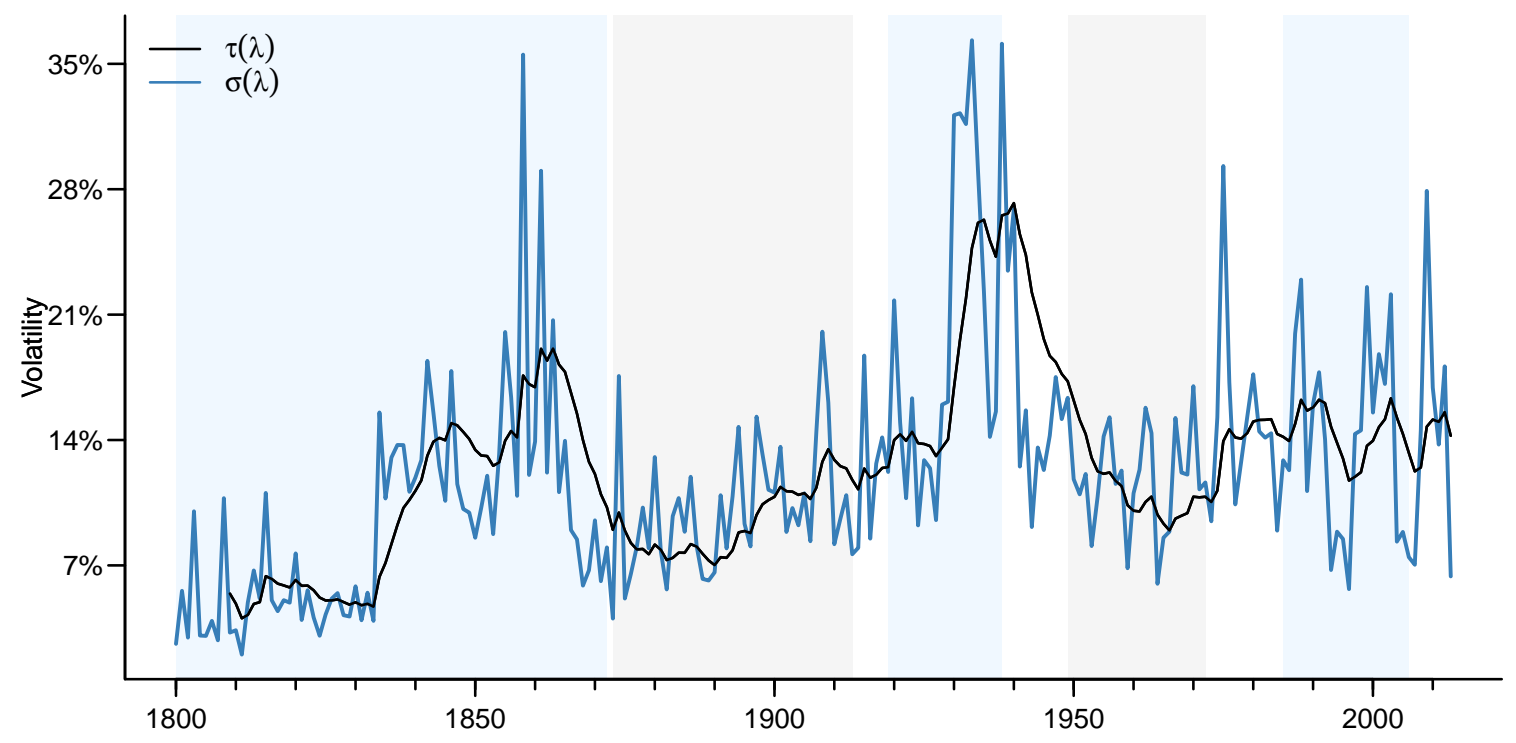

(a) Trend and volatility

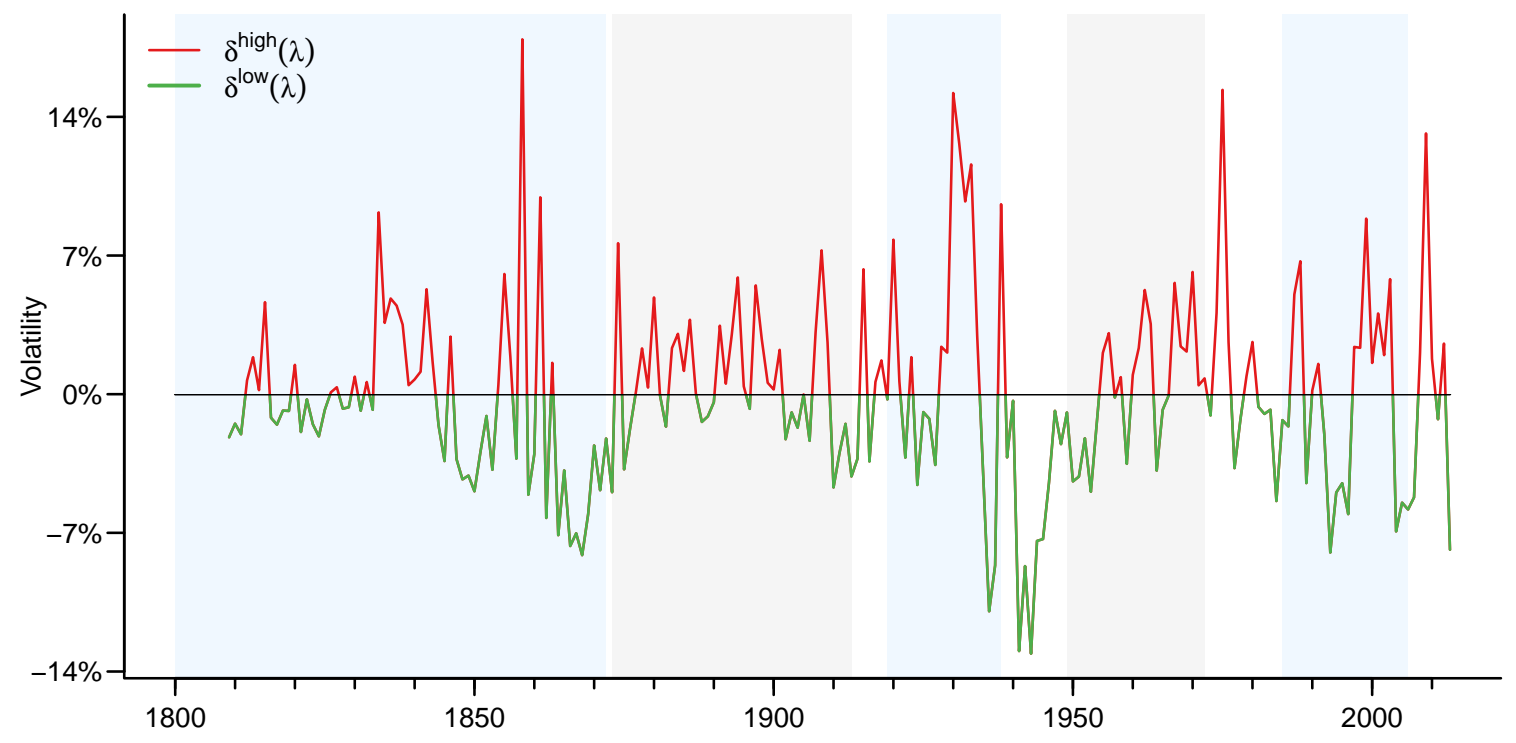

(b) High and low volatility 
areas in which volatility is higher and lower than the trend for the United States, while Panel (b) shows the high and low deviations from trend-i.e., $\delta_{t}^{\text {high }}$ and $\delta_{t}^{\text {low }}$.

\section{Econometric methodology}

\subsection{Model construction}

We regress the binary crisis indicator $C_{i, t}^{k}$, which shows whether a crisis of type $k$ started in country $i$ in year $t$, on lags of high and low volatility defined in Section $3, \delta^{\text {high }}$ and $\delta^{\text {low }}$. We also include control variables $(X)$ and fixed effects.

Instead of regressing the crisis indicator on lags of the explanatory variables, we follow Reinhart and Rogoff (2011), and use backward-looking moving averages of explanatory variables from $t-1$ to $t-L$. This procedure, in addition to reducing the collinearity between the explanatory variables, allows us to estimate what timescale is most relevant. For country $i$ and year $t$, we run the following logit-panel regression:

$$
\begin{aligned}
C_{i, t}^{k} & =\beta_{1} \bar{C}_{i, t-1 \text { to } t-L}^{k}+\beta_{2} \bar{\delta}_{i, t-1 \text { to } t-L}^{\text {high }}(\lambda)+\beta_{3} \bar{\delta}_{i, t-1 \text { to } t-L}^{\text {low }}(\lambda) \\
& +\beta_{4} \bar{X}_{i, t-1 \text { to } t-L}+\nu_{t}+\eta_{i}+\varepsilon_{i, t}, \quad i=1, N
\end{aligned}
$$

where $\lambda$ is the HP filter smoothing parameter, and $\nu_{t}$ and $\eta_{i}$ are the time-series and cross-sectional fixed effects, respectively. When we use year and country fixed effects we face identification issues since crises are rare events and we use macroeconomic variables as controls. To overcome this problem, we opted to use less "granular" fixed effects at the decade and region level of aggregation, leaving the sensitivity analysis of fixed effects to the robustness section. Finally, the moving average variables are constructed as:

$$
\bar{z}_{i, t-1 \text { to } t-L}=\frac{1}{L} \sum_{i=1}^{L} z_{i, t}, \quad z=C, \delta, X .
$$




\subsection{Financial crisis data}

We base our analysis on the financial crises (banking, stock market, and currency) in Reinhart and Rogoff's (2009) database. ${ }^{4}$ A banking crisis is identified by (a) the closure, merger or public takeover of one or more financial institutions as a consequence of bank runs or (b) if there are no bank runs, the closure or large-scale government assistance of an important financial institution that leads to similar outcomes for other financial institutions. A currency crisis indicates a currency reform, such as an abandonment of a pegged exchange rate or a $15 \%$ or more depreciation of a currency with respect to the U.S. dollar (or the sterling, French franc, German mark or euro). Finally, following the definition of Barro and Ursua (2009), a cumulative decline of $25 \%$ or more in real equity prices signals a stock market crisis.

The database includes 70 countries spanning the period from 1800 to 2010. However, the coverage of countries with sufficiently long volatility histories is somewhat smaller at 60. Hence, that becomes our final cross-section size. In total, we observe 262 banking, 419 stock market and 540 currency crises. Combined with volatility data, our sample includes about 3,500 country-year pairs.

Figure 6 shows the data coverage. More crisis data are available than volatility data, especially at the beginning of the sample period. For example, volatility is available only for the United States, Great Britain, Germany, and France until the mid-1900s. In the 1920s the sample covers 10 countries, reaching 30 countries by the 1940s.

\subsection{Control variables}

Besides time-series and cross-sectional fixed effects, we control for specific circumstances that may provide alternative explanations with country specific control variables. In particular, we consider lags of the crisis dummy, GDP per capita, inflation, change in government debt and institution quality.

\footnotetext{
${ }^{4}$ As noted in the robustness section, we also compare and merge it with the financial crisis histories of Bordo et al. (2001); Laeven and Valencia (2008); Gourinchas and Obstfeld (2012); Schularick and Taylor (2012) by using consistent definitions of crises. We obtain qualitatively similar results. However, for consistency purposes we opted to employ the most comprehensive database both in time-series and cross-sectional dimensions.
} 
Figure 6: Data Coverage

Number of countries with available volatility and crisis data.

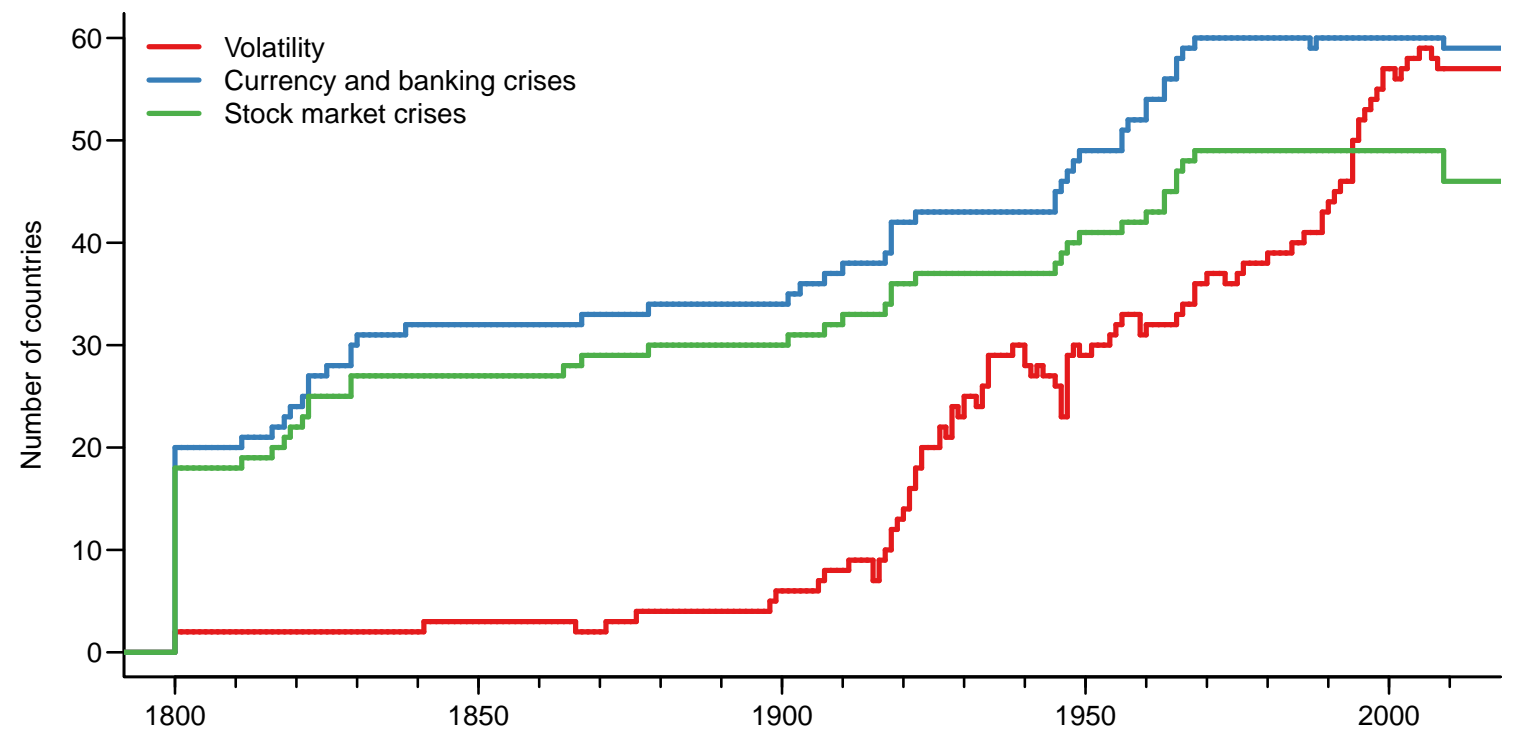

Following Demirguc-Kunt and Detragianhe (1998) and Cavallo and Frankel (2008), we use the natural logarithm of GDP per capita $(\ln G D P)$, obtained from the Maddison economic database of Bolt and van Zanden (2014). Since we are considering the impact of real financial market volatility on crisis probabilities, it is also natural to control for the level of inflation, calculated as the annual percentage change in the consumer price index, obtained from Global Financial Data.

In addition, as government debt potentially affects the probability of a crisis, we also include $\triangle P D / G D P$, the change in gross central government debt-to-GDP ratio, in the regression specification. The data are obtained from Reinhart and Rogoff (2010).

Institutional characteristics and governance of a country can affect political and macroeconomic stability (Alesina et al., 1992; Acemoglu et al., 2003; Cerra and Saxena, 2008). Therefore, we use the POLCOMP variable from the Polity IV Project database as a proxy for "institutional quality". POLCOMP is the combination of the degree of institutionalization or regulation of political competition and the extent of government restriction on political competition. The higher the value of the POLCOMP, the better the institution quality of a given country. 


\subsection{Econometric considerations}

There are some considerations that have to be taken into account in the estimation. First, one needs to decide on the time period over which to calculate the annual volatilityJanuary to December, July to June, or any other 12-month period. After all, all that is known is whether a crisis happened in a given year, not the month of the crisis. Even if the beginning month of crisis is marked, it is hard to verify the precise timing of a crisis as it could have realistically started earlier. For banking crises for instance, an actual bank run or receipt of government assistance usually comes well after the financial problems start. We opted for mid-year volatility estimates, calculated by using returns from July to June of a given year and discuss other alternatives in the robustness analysis. Specifically, to estimate volatility for year $t$, we employ monthly return observations from July in year $t-1$ up to June in year $t$.

Second, one needs to decide the value of $L$ in (3). Theory only suggests that past levels of volatility affect the future incidence of crises, but not how far back to look. The answer could easily depend on the time period or the country under consideration (see for instance Aguiar and Gopinath, 2007, who show that the business cycles of emerging countries are shorter than the developed ones). In what follows, we opted for five years, but the robustness analysis suggests that the results are robust to using fewer or more years.

Finally, since we estimate high and low volatility with HP filtering we need to specify the smoothing parameter $\lambda$. The choice of $\lambda$ depends on the nature of the underlying timeseries. For instance, for annual GDP data from the United States, Hodrick and Prescott (1997) propose a $\lambda$ equal to 100 . Given that our series is stock market volatility and it is more volatile compared to a macroeconomic series, like GDP, we chose a larger smoothing parameter. Otherwise, the procedure would assign a very large fraction of swings to the trend, making it almost the same as volatility itself. In the baseline specifications, we set $\lambda=5,000$; however, we investigate other alternatives in the robustness analysis.

\section{Results}

Our regression analysis shows the impact of volatility on the probability of future crises within a panel-logit regression framework. We focus on three different specifications 
of volatility: the annual level of volatility $(\sigma)$, volatility above its trend $\left(\delta^{\text {high }}\right)$, and volatility below its trend $\left(\delta^{\text {low }}\right)$. In what follows, we refer to these as level, high, and low volatilities, respectively.

\subsection{Volatility and crisis}

The first relationship we consider is how the volatility level relates to the probability of future crises, presented in Table 1 . When considered on its own as an independent variable, $\sigma$ is statistically significant, but the significance does not survive the inclusion of control variables. This result suggests that any impact of the level of volatility on the likelihood of future crises is fully captured by the control variables, especially the debt-to-GDP ratio and inflation.

The theoretical literature suggests that both unexpectedly high and low volatility affect agents' decision making, leading to a deterioration of financial conditions. If the impact of these two effects is different, it is possible that the level of volatility is insignificant while high and low volatility are significant. This motivates the separation of high and low volatility channels, which is confirmed by the results in Table 2 .

For banking crises, the coefficient of both high and low volatility is positive and significant in the absence of control variables. Since we use the absolute value of low volatility, the higher the $\delta^{\text {high }}$ and $\delta^{\text {low }}$ are, the farther away volatility is from its long-run trend in either direction and the higher the likelihood of a crisis. We observe that the economic impact of low volatility is higher than that of its high volatility counterpart. Moreover, only $\delta^{\text {low }}$ survives the inclusion of control variables. The strong prediction of $\delta^{\text {low }}$ is in line with theoretical results where low volatility induces excessive risk-taking, leading to future credit problems and difficulties for banks. High volatility is not significant in the presence of control variables, indicating that for banking crises, the low volatility channel matters, not the high channel, lending support to Chair Yellens observation at the start of the paper.

For stock market crises, both the $\delta^{\text {low }}$ and $\delta^{\text {high }}$ coefficients are positive and significant, with and without the control variables. A higher-than-expected volatility could reflect the increased uncertainty about future economic conditions, where a negative eventuality would cause prices and stock markets to sharply fall. At the same time, long periods of low volatility may also induce excessive risk-taking in a Minsky-type scenario, also 
indicating a higher chance of a future stock market crisis. Furthermore, since the probability of a stock market crisis derives from the same stochastic process as volatility, it may well be that more extreme high or low volatilities could indicate that the tails of the return process are becoming fatter, increasing the probability of a crisis.

In the robustness analysis we investigate the impact of different lag lengths, finding that the low channel is most important farther away from a stock market crisis while the high channel operates much closer to a crisis. This further supports the theoretical literature where the low channel affects the risk-taking behavior while the high channel is more of a signal of a pending crisis event.

By contrast, volatility has no impact on currency crises regardless of whether the control variables are included. This is not entirely unexpected; among the three financial crisis types considered here, currency is the most closely connected to the macroeconomy and the connection to financial market volatility is the most tenuous.

The observation that the level of volatility is not a significant predictor of crises when controlled for macroeconomic variables leaves the question of the extent to which the control variables predict volatility. We find that about half of the variation in volatility can be explained (adj. $R^{2}$ ) by macroeconomic variables, where it is only $11 \%$ and $16 \%$ for high and low volatility, respectively. Therefore, if one wants to capture the impact of deviations of risk from what economic agents expected, it is necessary to look at the high and low decomposition; otherwise, one might as well just look at the macroeconomic dynamics.

\subsection{The macroeconomy, politics, and crises}

In addition to volatility, we control for four variables: institutional quality, inflation, debt-to-GDP ratio, and GDP. We find that higher institutional quality of a country significantly lowers the probability of a banking crisis. It could be that governance is better for countries with better-quality scores, where it is more difficult for politicians to distort banks' lending decisions.

Results show that higher inflation increases the probability of banking and stock market crises. The former observation is consistent with the current literature (see, for instance, 
Demirguc-Kunt and Detragianhe, 2005, for a comprehensive survey on the determinants of banking crises).

Interestingly, we find that the increase in debt-to-GDP ratio is negatively associated with the probability of a future banking crisis. This is in line with the experience of the European sovereign debt crisis. Iceland and Ireland, the two countries where the banking system was the most direct cause of the sovereign crisis, had low initial sovereign debt levels, whereas the more indebted crisis countries, such as Portugal and Greece, had more conservative banking systems that only suffered as a consequence of the sovereign difficulties.

Finally, the level of GDP does not matter for banking or stock market crises, but countries with a lower GDP have a higher incidence of currency crises.

\subsection{Volatility and crises: sub-periods}

Throughout the sample period, we witness many different economic and market structures. In the beginning of the sample, we have very few countries and no electronic communication, while in 2010 we have advanced integrated financial and economic systems. Moreover, the structure of the banking system, stock market developments, and capital restrictions have changed dramatically.

In addition several different currency systems were in operation; the gold standard with the occasional realignment pre-World War I, some countries temporarily returning to the gold standard in the interwar years, followed by the fixed exchange rate regimes of the Bretton Woods era, and a variety of arrangements since then. Not surprisingly, the frequency of crises has been changing. The pre-World War I era has the lowest frequency of crises, while the interwar and Great Moderation periods are more crisis prone.

In the specific context of volatility, stock markets have become steadily more important over time. In the earliest part of the sample, limited liability corporations were quite uncommon. Almost all banks were partnerships and hence had different incentives of risk-taking than recent banks, which are mostly limited liability corporations. Few economic agents had access to stock markets and banking. While individual bank accounts had become quite common in the United Kingdom by the mid-1800s, that was not the 
case for the other early history countries. Stock markets first start to play a major economic role in the interwar years, and then primarily in the United States.

In addition, volatility level changed dramatically following these developments throughout the sample period, as documented in Section 3.2. Ultimately these suggest to us that it is worthwhile to study the volatility-crises relationship in different sub-periods.

We use the same sub-periods introduced in Section 3.2, with two exceptions. First, we merge the pre-gold and gold standard eras under the early period (1800-1913), as the sample is otherwise too small for a proper statistical analysis. Second, since there are only two banking crises across all countries in the sample during the Bretton Woods era, it is not possible to estimate the model for that sub-period only and hence it is excluded from the regression analysis. The results are presented in Table 3.

In the pre-World War I period, we find that neither high nor low volatility is significant. Instead, the level of volatility is significant for stock market and currency crises, but not for banking crises, implying that the channel for which volatility affects financial crises in the early period is different than that of the 20th century.

The second subsample we look at is the period between the two world wars. This is the first time stock markets and banking, especially in the United States, became available to most economic agents and we had many more limited liability corporations than before. Both the high and low channels are significant for the stock market crises while low volatility is significant for banking crises. Interestingly, the high volatility channelbut not the low-volatility channel - is significant for currency crises, possibly because currency crises are most frequent at that time.

The final subsample is the postwar era. There is a natural breaking point in the mid1980s marking the start of the Great Moderation, when inflation was conquered and computers were used for financial trading. This is the period when markets were highly integrated due to technological improvements and the opening of capital flows. Similar to the whole sample, we find that during the Great Moderation, both the high and low volatility channels are significant for stock market crisis, while for banking crisis only the low volatility channel matters. Meanwhile, for currency crises, neither channel is significant. 


\subsection{On the reliability of unexpected volatility as a crisis pre- dictor}

While our results reveal that current unexpected volatility indicates that a financial crisis is more likely a few years down the road, they do not by themselves suggest that high or low volatility would be a valuable early warning indicator. Assessing the reliability of unexpectedly high and low volatility as indicators of a future crisis is of key interest for policymakers, and for that reason we examine such a predictability along two dimensions. First, we formally evaluate the degree of type I and type II errors - the tradeoff between missing actual distress episodes and creating false alarms. Second, as in-sample regressions give rise to the potential for the forecast results being affected by look-ahead bias, we examine the out-of-sample forecasting performance of high and low volatility.

One standard way to evaluate binary classification ability is to calculate the area under the receiver operating characteristic curve (AUROC), which is a test of whether the signals are distributed significantly different under crisis and non-crisis periods. The AUROC provides a measurement of the accuracy of a signal by considering the true positive rate (signal ratio) against the false positive rate (noise ratio) for every possible threshold value. As the threshold increases, the number of crisis signals drops, so fewer crises are correctly identified and incorrectly signaled, while under a lower threshold more crises are correctly identified while the frequency of false signals also increases. A key advantage of the AUROC approach is that it does not rely on a specific threshold; consequently it has been widely used as an evaluation criterion in recent literature, including Berge and Jorda (2011); Candelon et al. (2012), and Schularick and Taylor (2012).

If a signal is non-informative, equivalent to the toss of a coin, the AUROC would be $50 \%$. In our case, we find that for banking crises the AUROC is $81 \%$, with a $95 \%$ confidence interval of $[77 \%, 84 \%]$; for stock market crises, the AUROC is $70 \%$ with a $95 \%$ confidence interval of $[67 \%, 72 \%]$. This clearly indicates that unexpected volatility signals a crisis significantly better than random noise. While there is no established cut-off value in the literature to classify an indicator as strong, Schularick and Taylor (2012) find an AUROC of $72 \%$ for the predictive ability of credit booms on a banking crisis. 
To evaluate the out-of-sample performance, we split the panel into two subsample periods: the training period $\left(T_{\text {train }}\right)$ and the testing period $\left(T_{\text {test }}\right)$ with $T_{\text {train }}+T_{\text {test }}=T$, the total number of years. Then, for a subsample of observations up to $t=T_{\text {train }}$, we estimate the logit-panel regression model from (3) without control variables but with fixed effects at the region and decade level. Having the estimated coefficients, we compute the predictive value of the model at $t+1\left(\widehat{C}_{t+1}\right)$ for each country. We repeat this procedure from $T_{\text {train }}$ up to $T-1$ by adding one year of observation each iteration. We then calculate the pseudo- $R^{2}$ of Estrella (1998); Estrella and Mishkin (1998), defined for each country as

$$
\text { pseudo- } R^{2}=1-\left(\frac{\log L u}{\log L c}\right)^{-\frac{2}{T_{\text {test }}} \log L c},
$$

where $L u$ and $L c$ are the log-likelihood of the unrestricted model and a model that only includes fixed effects. The log-likelihood is obtained as:

$$
\log L=\sum_{T_{\text {train }}+1}^{T} C_{t} \log \left(\widehat{C}_{t}\right)+\left(1-C_{t}\right) \log \left(1-\widehat{C}_{t}\right)
$$

where $C_{t}$ and $\hat{C}_{t}$ are the realized and the predicted probability of recession for years $t$. Finally, we get the cross-sectional averages of pseudo- $R^{2} \mathrm{~s}$. If the inclusion of high and low volatility, in addition to fixed effects, delivers better out-of-sample performance than fixed-effects only, then we should observe positive pseudo- $R^{2} \mathrm{~s}$.

We calculate the pseudo- $R^{2}$ for a range of $T_{\text {train }}$ finding positive values in all cases. For example, setting $T_{\text {train }}$ to 1965 , the pseudo- $R^{2}$ is $17 \%$ and $13.5 \%$ for banking and stock market crises, respectively. For $T_{\text {train }}$ set to 1980 , the pseudo- $R^{2}$ improves up to $20.6 \%$ when predicting banking crises, whereas it slightly decreases to $11.4 \%$ for stock market crises.

We agree with the early warning literature's healthy skepticism of the quality of indicators; hence, we are reluctant to recommend high and low volatility as early warning indicators. However, our results suggest that unexpected volatility provides a statistically significant indication of future crises both in-sample and out-of-sample, delivering a fair signal-to-noise ratio; therefore, it should be seriously considered by policymakers as a guidance on the volatilitycrises relationship. 


\subsection{Robustness}

Our main results, as presented so far, are based on a plausible set of model and parameter assumptions. As usual, there is more than one way to make many of these assumptions, and in this section we consider several alternative cases to test robustness.

We first examine different ways of capturing the high and low volatility channels. Perhaps the most obvious is the deviation from a mean rather than deviation from a trend. We calculate the average historical volatility using 10 years of moving windows and then obtain high and low volatility analogously as in (2). Alternatively, one can define high and low volatility based on a threshold. Inspired by Loayza et al. (2007), we calculate volatility that corresponds to large positive and negative fluctuations in a one-standard deviation band.

Second, we check whether our findings are sensitive to the definition of volatility. In the baseline specification, we calculate annual volatility as the standard deviation of 12 monthly mid-year (July to June) returns. However, there is no obvious reason to believe that June to July would be better than any other 12-month period. Thus, we first test the results when volatility is calculated by employing monthly returns up to March, September, and December. For the sake of brevity, we present the end-year results only. In addition, following Mele (2007); Fornari and Mele (2009); Corradi et al. (2013), we measure volatility as the sum of absolute monthly returns, instead of standard deviation.

Third, we examine whether the empirical methodology and model specification matters. We consider other fixed effect specifications and different $L$ values in (3). The expected level of volatility might also matter and hence we investigate whether our results are sensitive to the inclusion of the trend $(\tau)$ estimated through the HP filter in the baseline specification.

Fourth, we examine the sensitivity of the results to the smoothing parameter $\lambda$ in the HP procedure. We consider $\lambda=100,1000$, and 10,000 but as the results are qualitatively similar, for concision we report the results only with $\lambda=100$.

Fifth, we investigate whether our main results are still present if we use a different sample. Specifically, we exclude the most volatile periods, in particular the interwar period, the two world wars, and post-2006. Then, we use the merged databases of Bordo et al. (2001); Laeven and Valencia (2008); Gourinchas and Obstfeld (2012); Schularick 
and Taylor (2012) with that of Reinhart and Rogoff (2009), for banking and currency crises.

Overall, Tables 4-6 reveal that the results are qualitatively unaltered under the various robustness checks. There are small changes in specific parameter values, but the main conclusions of the importance of high and low volatilities and the control variables hold up.

The two main exceptions are the time of the year used to calculate the annual volatility and the number of years used for historical averaging, both of which matter particularly in predicting stock market crises. First, when end-year, instead of mid-year returns are used to calculate annual volatility-i.e., when returns closer to a crisis are taken into account - the economic importance of high volatility increases monotonically and dominates low volatility. Second, when information during the last three years is used to calculate the historical averages for high and low volatility, we find that only high volatility matters for predicting stock market crises, whereas low volatility becomes important only when agents observe low levels of volatility for a "long-enough" period, such as five years. Accordingly when we consider volatility during the last seven years, low volatility becomes the only significant predictor of a stock market crisis.

Finally, we find that low volatility Granger causes high volatility, but not vice versa. These results are consistent with what one would expect from the economic theorythe low volatility channel induces risk-taking and as we move through time, volatility increases at the onset of a crisis.

\section{Risk-taking and the volatility channels}

The presence of the low volatility channel is motivated by low risk encouraging economic agents to engage in risk-taking that ultimately leads to a crisis - what is often termed the "Minsky hypothesis".

We could not investigate this using the whole sample because no variable capturing risk-taking exists until later in the sample and the earliest risk-taking proxies do not cover the whole cross-section. Even in more recent history, measuring risk-taking is not straightforward. One could use bank-level data, such as bank capital-to-asset ratio or 
non-performing loans ratio, but such data are quite restrictive, and it is difficult, if not impossible, to aggregate at the country level.

We instead employ the credit-to-GDP gap as a proxy for risk-taking. Here we have the benefit of two alternative measures, one cross-sectionally comprehensive but shorter in time and the other with a fairly long history but only covering a few countries.

Our first measure adopts the Basel Committee on Banking Supervision's credit-to-GDP ratio gap, which is identified and used as a signaling device for the build-up of excessive leverage for banks (Alessi and Detken, 2014). Indeed, Drehmann et al. (2010, 2011) show that it outperforms other early warning indicators such as GDP, credit growth, and their ratios, as well as other banking sector performance measures.

The Basel Committee's credit-to-GDP ratio gap is defined as the difference between the actual credit-to-GDP ratio and the long-run trend, where the HP filter is used to extract the trend. The Basel Committee's 2010 consultative document considers a range of values for the smoothing parameter. We opt for its median value of $\lambda=100$, but did consider others without any significant changes to the results. ${ }^{5}$ We obtain aggregate private sector credit data from the BIS and nominal GDP data from the WDI. The downside is that these data are only available from the 1960s for 35 countries.

We also make use of Schularick and Taylor's (2012) dataset of annual aggregate bank loans and total assets for the banking sector, from 1870 for 14 developed countries. Total loans are defined as the end-of-year amount of outstanding domestic currency lending by domestic banks to domestic households and non-financial corporations (excluding lending within the financial system). Total bank assets is the sum of all balance sheet assets of banks with national residency (excluding foreign currency assets). Thus, we use bank loans and assets, normalized by nominal GDP (also obtained from the same dataset), to calculate the credit-to-GDP ratio and again use credit gap as a proxy for risk-taking.

The credit-to-GDP gap may not be the best variable to use because it tends to adjust slowly following a long period of negative credit growth. In addition, a higher gap could be due to either excessive credit growth or low output growth, meriting different policy

\footnotetext{
${ }^{5}$ For quarterly data, $\lambda=1,600,25,000,125,000$, and 400,000, are equivalent to $\lambda=6,100,500$, 1,500 in annual data (Ravn and Uhlig, 2002). This assumes that the credit cycle is the same, double, triple, and quadruple as the length of the business cycle of $7 \frac{1}{2}$ years.
} 
responses (see, for instance Edge and Meisenzahl, 2011; Alessi and Detken, 2014). We therefore also use the growth of the credit-to-GDP ratio as a proxy for risk-taking.

To examine whether low volatility for a prolonged period of time leads to an increase in risk-taking behavior, we regress risk-taking on high and low volatility in addition to the same control variables as in (3):

$$
\begin{aligned}
\operatorname{RiskTaking}_{i, t} & =\beta_{1} \bar{\delta}_{i, t-1 \text { to } t-5}^{\text {high }}(\lambda)+\beta_{2} \bar{\delta}_{i, t-1 \text { to } t-5}^{\text {low }}(\lambda)+\beta_{3} \overline{\operatorname{RiskTaking}}_{i, t-1} \text { to } t-5 \\
& +\beta_{4} \bar{X}_{i, t-1 \text { to } t-5}+\nu_{t}+\eta_{i}+\varepsilon_{i, t}
\end{aligned}
$$

where RiskTaking is either the level of credit-to-GDP ratio gap or the difference of log-credit, calculated using BIS and Schularick and Taylor (2012) data, respectively.

The results reported in Table 7 show that the estimated coefficient of low volatility is positive and significant irrespective of the definition of risk-taking and the database employed. Hence, we find strong support that unexpectedly low levels of financial volatility are followed by credit booms, supporting the Minsky's instability hypothesis. Persistently low volatility alters agents' expectations and allows for imbalances to build up as agents take higher risks.

\section{Conclusion}

In this paper, we create an extensive dataset of financial market volatility from primary sources, spanning 60 countries and up to 211 years. This is used to investigate the relationship between volatility and financial crises via a two-way fixed effects dynamic panel-logit analysis. We further decompose volatility into unexpectedly high and low deviations from its trend to investigate theoretical predictions that emphasize the asymmetry of the impact of high and low volatility on agents' decisions.

We find that volatility is generally not a significant predictor of financial crises but unexpected high and low volatilities are significant predictors. When considering the varieties of crises, both high and low volatility matter for stock market crises, while low volatility is more important for banking crises. Volatility does not seem to predict currency crises except in the inter-war years. These results are robust to formal out-ofsample analysis. 
Past inflation and debt-to-GDP ratios explain a considerable part of current volatility, but not high and low volatilities. We find that the relationship between unexpected volatility and the incidence of a crisis becomes stronger over time, consistent with the observation that stock markets have grown in importance over the 211 year sample.

Finally, we find direct support for the mechanism of the Minsky hypothesis where agents become more optimistic about future economic conditions during long-lasting low volatility periods, which in turn leads to higher risk taking.

We are not aware of any empirical work documenting most of these phenomena.

These results should be of value to macro-prudential and monetary policy policymakers, as they provide guidance on how one should think about the relationship between financial market risk and the macroeconomy. 


\section{References}

Acemoglu, D., S. Johnson, J. Robinson, and Y. Thaicharoen (2003). Institutional causes, macroeconomic symptoms: Volatility, crises and growth. Journal of Monetary Economics 20, 49-123.

Aguiar, M. and G. Gopinath (2007). Emerging market business cycles: The cycle is the trend. Journal of Political Economy 115, 69-102.

Alesina, A., S. Ozler, N. Roubini, and P. Swagel (1992). Political instability and economic growth. Journal of Economic Growth 1, 189-211.

Alessi, L. and C. Detken (2014, August). Identifying excessive credit growth and leverage. ECB Working Paper Series 1546.

Barro, R., J. and F. Ursua, J. (2009). Stock market crashes and depressions. Technical Report 14760, NBER Working Paper.

Basel Committee on Banking Supervision (2010). Countercyclical capital buffer proposal. Technical report, Bank for International Settlements.

Berge, T., J. and O. Jorda (2011). Evaluating the classification of economic activity into recessions and expansions. American Economic Journal: Macroeconomics 3, 246-277.

Bernanke, B. (2012). The Great Moderation, pp. 145-162. Hoover Institution Press.

Bhattacharya, S., C. Goodhart, D. Tsomocos, and A. Vardoulakis (2015). A reconsideration of Minsky's financial instability hypothesis. Journal Money Credit and Banking Forthcoming.

Blanchard, O. and J. Simon (2001). The long and large decline in U.S. output volatility. Brookings Papers on Economic Activity 1, 135-174.

Bolt, J. and J. L. van Zanden (2014). The Maddison Project: Collaborative research on historical national accounts. The Economic History Review 67, 627-651.

Bordo, M., B. Eichengreen, D. Klingebiel, S. M. Martinez-Peria, and A. K. Rose (2001). Is the crisis problem growing more severe? Economic Policy 24, 51-82. 
Brunnermeier, M. and Y. Sannikov (2014). A macroeconomic model with a financial sector. American Economic Review 104, 379-421.

Candelon, B., E. Dumitrescu, and C. Hurlin (2012). How to evaluate an early-warning system: Toward a unified statistical framework for assessing financial crises forecasting methods. Technical Report 60, IMF Economic Review.

Cavallo, E., A. and A. Frankel, J. (2008). Does openness to trade make countries more vulnerable to sudden stops, or less? Using gravity to establish causality. Journal of International Money and Finance 27, 1430-1452.

Cerra, V. and S. C. Saxena (2008). Growth dynamics: The myth of economic recovery. American Economic Review 98, 439-457.

Corradi, V., W. Distaso, and A. Mele (2013). Macroeconomic determinants of stock volatility and volatility premiums. Journal of Monetary Economics 60, 203-220.

Danielsson, J., H. S. Shin, and J.-P. Zigrand (2012). Procyclical leverage and endogenous risk. Mimeo, LSE, http://www.riskresearch.org.

Demirguc-Kunt, A. and E. Detragianhe (1998, March). The determinants of banking crises in developing and developed countries. IMF Working Paper.

Demirguc-Kunt, A. and E. Detragianhe (2005, May). Cross-country empirical studies of systemic bank distress: A survey. IMF Working Paper, WP/05/96.

Dixit, A. K. and R. S. Pindyck (1994). Investment under Uncertainty. Princeton University Press.

Drehmann, M., C.Borio, L. Gambacorta, G. Jimenez, and C. Trucharte (2010, July). Countercyclical capital buffers: Exploring options. BIS Working Paper.

Drehmann, M., C.Borio, and K. Tsatsaronis (2011, November). Anchoring countercyclical capital buffers: The role of credit aggregates. BIS Working Paper.

Edge, R. and R. Meisenzahl (2011). The unreliability of credit-to-GDP ratio gaps in real time: Implications for countercyclical capital buffers. International Journal of Central Banking 7, 261-298. 
Estrella, A. (1998). A new measure of fit for equations with dichotomous dependent variables. Journal of Business \& Economic Statistics 16, 198-205.

Estrella, A. and F. Mishkin (1998). Predicting U.S. recessions: Financial variables as leading indicators. The Review of Economics and Statistics 80, 45-61.

Fornari, F. and A. Mele (2009). Financial volatility and economic activity. Financial Markets Group Discussion Paper No. 642.

Gourinchas, P.-O. and M. Obstfeld (2012). Stories of the twentieth century for the twenty-first. American Economic Journal: Macroeconomics 8, S85-S118.

Hamilton, J., D. and G. Lin (1996). Stock market volatility and business cycle. Journal of Applied Econometrics 11, 573-593.

Han, L. (2013). Understanding the puzzling risk-return relationship for housing. Review of Financial Studies 26, 877-928.

Hayek, F. (1960). The Constitution of Liberty. Routledge.

Hodrick, R., J. and C. Prescott, E. (1997). Postwar US business cycles: an empirical investigation. Journal Money Credit and Banking 29, 1-16.

Jorda, O., M. Schularick, and A. M. Taylor (2010). Financial crises, credit booms, and external imbalances: 140 years of lessons. Technical Report 16567, NBER Working Paper.

Keynes, J. M. (1936). The General Theory of Interest, Employment and Money. London: Macmillan.

Laeven, L. and F. Valencia (2008). Systemic banking crises: A new database. Technical report, IMF Working paper WP/08/224.

Loayza, N., R. Ranciere, L. Serven, and J. Ventura (2007). Macroeconomic volatility and welfare in developing countries: An introduction. The World Bank Economic Review 21, 343-357.

Mele, A. (2007). Asymmetric stock market volatility and the cyclical behavior of expected returns. Journal of Financial Economics 86, 446-478. 
Minsky, H. (1992). The financial instability hypothesis. Working Paper 74, Jerome Levy Economics Institute, Annandale on Hudson, NY.

Muler, N. and V. Yohai (2008). Robust estimates for GARCH models. Journal of Statistical Planning and Inference 138, 2918-2940.

Ranciere, R., A. Tornell, and F. Westermann (2015). Systemic crises and growth. Quarterly Journal of Economics forthcoming.

Ravn, M., O. and H. Uhlig (2002). On adjusting the Hodrick-Prescott filter for the frequency of observations. Review of Economics and Statistics 84, 371-376.

Reinhart, C. M. and K. S. Rogoff (2009). This Time is Different: Eight Centuries of Financial Folly. Princeton University Press.

Reinhart, C. M. and K. S. Rogoff (2010). Growth in a time of debt. American Economic Review: Papers $\&$ Proceedings 100, 573-578.

Reinhart, C. M. and K. S. Rogoff (2011). From financial crash to debt crisis. American Economic Review 101, 1676-1706.

Samuelson, P. (1966). Science and stocks. Newsweek.

Schularick, M. and A. Taylor (2012). Credit booms gone bust: Monetary policy, leverage cycles, and financial crises, 1870-2008. American Economic Review 102, 1029-1061.

Schwert, G. W. (1989). Business cycles, financial crises, and stock volatility. CarnegieRochester Conference Series on Public Policy 31, 83-125.

Schwert, G. W. (1990). Stock volatility and crash of 1987. Review of Financial Studies 3, $77-102$.

Wahal, S. and M. Yavuz, D. (2013). Style investing, comovement and return predictability. Journal of Financial Economics 10\%, 136-154.

Yellen, J. (2014). Press Conference, Federal Reserve Board. June, 18. 
Table 1: Regression results: Volatility level

This table presents the results for the panel-logit regressions, where the variable of interest is annual volatility, $\sigma$. In Columns I and II, the dependent variable is a dummy variable that takes the value 1 in the first year of a banking crisis. Similarly, the results for stock market and currency crises are presented in Columns III-IV and V-VI, respectively. $\log G D P$ is the natural logarithm of the GDP per capita, $\triangle P D / G D P$ is the change in public-debt-to-GDP ratio, $P O L C O M P$ is the degree of political competition and INFLATION is the annual inflation rate calculated using CPI data. Past five year averages of the explanatory variables are used in the regressions. All of the specifications include timeseries and cross-sectional fixed effects listed in the last two rows. For the sake of brevity, the estimated coefficients of fixed effects are omitted. The panel covers 60 countries and spans 1800-2010. The standard errors, reported in parentheses, are robust and clustered at the year level.

\begin{tabular}{lcc|cc|cc}
\hline & \multicolumn{2}{c}{$C_{i, t}^{\text {Banking }}$} & \multicolumn{2}{c}{$C_{i, t}^{\text {Stock }}$} & \multicolumn{2}{c}{$C_{i, t}^{\text {Currency }}$} \\
& $\mathrm{I}$ & $\mathrm{II}$ & $\mathrm{III}$ & $\mathrm{IV}$ & $\mathrm{V}$ & $\mathrm{VI}$ \\
\hline$C_{i, t-1 \text { to } t-5}$ & $-6.71^{* * *}$ & $-7.46^{* * *}$ & $-4.80^{* * *}$ & $-4.92^{* * *}$ & -0.95 & $-1.52^{* *}$ \\
& $(1.461)$ & $(1.543)$ & $(0.764)$ & $(0.762)$ & $(0.680)$ & $(0.731)$ \\
$\sigma_{i, t-1 \text { to } t-5}$ & $0.07^{* * *}$ & -0.01 & $0.05^{* *}$ & 0.02 & 0.01 & -0.00 \\
& $(0.022)$ & $(0.049)$ & $(0.020)$ & $(0.030)$ & $(0.020)$ & $(0.033)$ \\
$\log G D P_{i, t-1 \text { to } t-5}$ & & -0.04 & & 0.04 & & $-0.33^{* *}$ \\
& & $(0.209)$ & & $(0.166)$ & & $(0.140)$ \\
$\Delta P D / G D P_{i, t-1 \text { to } t-5}$ & & $-0.05^{* *}$ & & 0.00 & & 0.01 \\
& & $(0.020)$ & & $(0.009)$ & & $(0.007)$ \\
$P O L C O M P_{i, t-1}$ to $t-5$ & & $-0.07^{*}$ & & 0.00 & & -0.01 \\
& & $(0.041)$ & & $(0.026)$ & & $(0.024)$ \\
$I N F L A T I O N_{i, t-1 \text { to } t-5}$ & & $0.03^{* * *}$ & & $0.01^{*}$ & & -0.00 \\
& & $(0.010)$ & & $(0.006)$ & & $(0.007)$ \\
\hline & & & & & & \\
Num of Obs. & 3,054 & 2,850 & 3,375 & 3,144 & 3,606 & 3,323 \\
Pseudo $R^{2}$ & 0.099 & 0.122 & 0.057 & 0.059 & 0.015 & 0.024 \\
Cross-sec. FE & Region & Region & Region & Region & Region & Region \\
Time-series FE & Decade & Decade & Decade & Decade & Decade & Decade \\
\hline
\end{tabular}


Table 2: Regression results: High and low volatility

This table presents the results for the regression equation introduced in (3). In Columns I and II, the dependent variable is a dummy variable that takes the value 1 in the first year of a banking crisis. Similarly, the results for stock market and currency crises are presented in Columns III-IV and V-VI, respectively. $\delta^{\text {high }}$ and $\delta^{\text {low }}$ are high and low volatility introduced in (2). $\log G D P$ is the natural logarithm of the GDP per capita, $\triangle P D / G D P$ is the change in public-debt-to-GDP ratio, POLCOMP is the degree of political competition and INFLATION is the annual inflation rate calculated using CPI data. Past five year averages of the explanatory variables are used in the regressions. All of the specifications include time-series and cross-sectional fixed effects listed in the last two rows. For the sake of brevity, the estimated coefficients of fixed effects are omitted. The panel covers 60 countries and spans 1800-2010. The standard errors, reported in parentheses, are robust and clustered at the year level.

\begin{tabular}{|c|c|c|c|c|c|c|}
\hline & \multicolumn{2}{|c|}{$C_{i, t}^{\text {Banking }}$} & \multicolumn{2}{|c|}{$C_{i, t}^{\text {Stock }}$} & \multicolumn{2}{|c|}{$C_{i, t}^{\text {Currency }}$} \\
\hline & I & II & III & IV & V & VI \\
\hline \multirow[t]{2}{*}{$\overline{C_{i, t-1} \text { to } t-5}$} & $-7.32^{* * *}$ & $-7.86^{* * *}$ & $-4.60 * * *$ & $-4.91 * * *$ & -1.22 & $-1.89^{* *}$ \\
\hline & $(1.793)$ & $(1.931)$ & $(0.827)$ & $(0.832)$ & $(0.764)$ & $(0.811)$ \\
\hline \multirow[t]{2}{*}{$\delta_{i, t-1 \text { to } t-5}^{\text {high }}$} & $0.26^{* * *}$ & $0.20^{*}$ & $0.15^{* * *}$ & $0.15^{* *}$ & 0.03 & -0.03 \\
\hline & $(0.084)$ & $(0.107)$ & $(0.054)$ & $(0.064)$ & $(0.063)$ & $(0.084)$ \\
\hline \multirow[t]{2}{*}{$\delta_{i, t-1}^{\text {low }}$ to $t-5$} & $0.30^{* * *}$ & $0.31^{* * *}$ & $0.22^{* * *}$ & $0.20^{* * *}$ & 0.06 & 0.06 \\
\hline & $(0.081)$ & $(0.096)$ & $(0.067)$ & $(0.076)$ & $(0.047)$ & $(0.047)$ \\
\hline \multirow[t]{2}{*}{$\log G D P_{i, t-1}$ to $t-5$} & & 0.07 & & 0.00 & & $-0.46^{* * *}$ \\
\hline & & $(0.258)$ & & $(0.207)$ & & $(0.148)$ \\
\hline \multirow[t]{2}{*}{$\triangle P D / G D P_{i, t-1}$ to $t-5$} & & $-0.07^{* * *}$ & & 0.00 & & 0.01 \\
\hline & & $(0.020)$ & & $(0.009)$ & & $(0.006)$ \\
\hline \multirow[t]{2}{*}{$P O L C O M P_{i, t-1}$ to $t-5$} & & $-0.09^{* *}$ & & 0.01 & & 0.01 \\
\hline & & $(0.041)$ & & $(0.030)$ & & $(0.024)$ \\
\hline \multirow[t]{2}{*}{$I_{N F L A T I O N} N_{i, t-1}$ to $t-5$} & & $0.02^{* *}$ & & $0.01^{* *}$ & & -0.01 \\
\hline & & $(0.008)$ & & $(0.005)$ & & $(0.005)$ \\
\hline Num of Obs. & 2,219 & 2,134 & 2,846 & 2,703 & 2,972 & 2,785 \\
\hline Pseudo $R^{2}$ & 0.083 & 0.106 & 0.060 & 0.063 & 0.020 & 0.031 \\
\hline Cross-sec. FE & Region & Region & Region & Region & Region & Region \\
\hline Time-series FE & Decade & Decade & Decade & Decade & Decade & Decade \\
\hline
\end{tabular}


Table 3: Regression Results: Sub-periods

This table presents the results for the regression equation introduced in (3) for different sub-periods for 60 countries. The early (1800-1913), interwar (1919-1938), and Great Moderation (1985-2006) periods are considered. In Columns I through III, the dependent variable is a dummy variable that takes the value 1 in the first year of a banking crisis. Similarly, the results for stock market and currency crises are presented in Columns IV-VI and VII-IX, respectively. $\delta^{\text {high }}$ and $\delta^{\text {low }}$ are high and low volatility introduced in $(2) . \log G D P$ is the natural logarithm of the GDP per capita, $\triangle P D / G D P$ is the change in public-debt-to-GDP ratio, POLCOMP is the degree of political competition and finally INFLATION is the annual inflation rate calculated using CPI data. Past five year averages of the explanatory variables are used in the regressions. Time-series and cross-sectional fixed effects used in the specifications are listed in the last two rows. For the sake of brevity, the estimated coefficients of fixed effects are omitted. The standard errors, reported in parentheses, are robust and clustered at the year level.

\begin{tabular}{|c|c|c|c|c|c|c|c|c|c|}
\hline & \multicolumn{3}{|c|}{$C_{i, t}^{\text {Banking }}$} & \multicolumn{3}{|c|}{$C_{i, t}^{\text {Stock }}$} & \multicolumn{3}{|c|}{$C_{i, t}^{\text {Currency }}$} \\
\hline & $\begin{array}{c}\text { Early period } \\
\text { I }\end{array}$ & $\begin{array}{c}\text { Inter-war } \\
\text { II }\end{array}$ & $\begin{array}{l}\text { Great Mod. } \\
\text { III }\end{array}$ & $\begin{array}{l}\text { Early period } \\
\text { IV }\end{array}$ & $\begin{array}{c}\text { Inter-war } \\
\mathrm{V}\end{array}$ & $\begin{array}{l}\text { Great Mod. } \\
\text { VI }\end{array}$ & $\begin{array}{l}\text { Early period } \\
\text { VII }\end{array}$ & $\begin{array}{c}\text { Inter-war } \\
\text { VIII }\end{array}$ & $\begin{array}{l}\text { Great Mod. } \\
\text { IX }\end{array}$ \\
\hline$C_{i, t-1}$ to $t-5$ & $\begin{array}{c}-11.58^{* * *} \\
(4.400)\end{array}$ & $\begin{array}{l}-7.93^{*} \\
(4.608)\end{array}$ & $\begin{array}{l}-6.11^{* *} \\
(2.497)\end{array}$ & $\begin{array}{c}-1.35 \\
(3.246)\end{array}$ & $\begin{array}{c}-21.85^{* * *} \\
(6.468)\end{array}$ & $\begin{array}{c}-4.48^{* * *} \\
(1.087)\end{array}$ & $\begin{array}{l}-20.06^{*} \\
(10.548)\end{array}$ & $\begin{array}{c}-17.78^{* * *} \\
(4.671)\end{array}$ & $\begin{array}{c}-1.01 \\
(1.218)\end{array}$ \\
\hline$\delta_{i, t-1 \text { to } t-5}^{\text {high }}$ & $\begin{array}{c}-0.76 \\
(0.737)\end{array}$ & $\begin{array}{c}-0.67 \\
(0.701)\end{array}$ & $\begin{array}{c}0.17 \\
(0.196)\end{array}$ & $\begin{array}{c}0.70 \\
(1.144)\end{array}$ & $\begin{array}{l}1.34^{* * *} \\
(0.486)\end{array}$ & $\begin{array}{c}0.33^{* * *} \\
(0.110)\end{array}$ & $\begin{array}{c}2.73 \\
(2.519)\end{array}$ & $\begin{array}{l}0.68^{* *} \\
(0.337)\end{array}$ & $\begin{array}{c}-0.11 \\
(0.133)\end{array}$ \\
\hline$\delta_{i, t-1}^{\text {low }}$ to $t-5$ & $\begin{array}{c}-0.86 \\
(1.279)\end{array}$ & $\begin{array}{l}0.38^{* *} \\
(0.185)\end{array}$ & $\begin{array}{l}0.34^{* *} \\
(0.137)\end{array}$ & $\begin{array}{c}-0.67 \\
(1.528)\end{array}$ & $\begin{array}{c}1.47^{* * *} \\
(0.410)\end{array}$ & $\begin{array}{l}0.31^{* * *} \\
(0.104)\end{array}$ & $\begin{array}{c}-2.83 \\
(2.274)\end{array}$ & $\begin{array}{l}-0.32 \\
(0.267)\end{array}$ & $\begin{array}{c}0.08 \\
(0.069)\end{array}$ \\
\hline $\log G D P_{i, t-1}$ to $t-5$ & $\begin{array}{c}2.64 \\
(3.925)\end{array}$ & $\begin{array}{c}-1.22 \\
(1.128)\end{array}$ & $\begin{array}{c}-0.22 \\
(0.269)\end{array}$ & $\begin{array}{c}0.60 \\
(2.154)\end{array}$ & $\begin{array}{l}4.86^{* * *} \\
(1.572)\end{array}$ & $\begin{array}{c}-0.23 \\
(0.237)\end{array}$ & $\begin{array}{l}16.77^{* *} \\
(7.950)\end{array}$ & $\begin{array}{c}1.33 \\
(1.137)\end{array}$ & $\begin{array}{l}-0.55^{* *} \\
(0.238)\end{array}$ \\
\hline$\Delta P D / G D P_{i, t-1}$ to $t-5$ & $\begin{array}{c}-0.14 \\
(0.154)\end{array}$ & $\begin{array}{c}-0.25^{* * *} \\
(0.075)\end{array}$ & $\begin{array}{l}-0.04 \\
(0.037)\end{array}$ & $\begin{array}{c}-0.20 \\
(0.253)\end{array}$ & $\begin{array}{c}-0.21^{* * *} \\
(0.076)\end{array}$ & $\begin{array}{c}0.00 \\
(0.008)\end{array}$ & $\begin{array}{l}0.42^{* *} \\
(0.202)\end{array}$ & $\begin{array}{c}0.18^{* * *} \\
(0.047)\end{array}$ & $\begin{array}{c}0.00 \\
(0.009)\end{array}$ \\
\hline$P O L C O M P_{i, t-1}$ to $t-5$ & $\begin{array}{c}0.14 \\
(0.226)\end{array}$ & $\begin{array}{c}0.06 \\
(0.117)\end{array}$ & $\begin{array}{l}-0.04 \\
(0.092)\end{array}$ & $\begin{array}{c}0.29 \\
(0.189)\end{array}$ & $\begin{array}{c}-0.34^{* * *} \\
(0.111)\end{array}$ & $\begin{array}{l}-0.00 \\
(0.057)\end{array}$ & $\begin{array}{l}1.66^{* *} \\
(0.680)\end{array}$ & $\begin{array}{l}-0.20 \\
(0.148)\end{array}$ & $\begin{array}{l}-0.05 \\
(0.075)\end{array}$ \\
\hline$I_{N F L A T I O N} N_{i, t-1}$ to $t-5$ & $\begin{array}{c}3.49 \\
(13.495) \\
\end{array}$ & $\begin{array}{c}-16.71 \\
(11.708) \\
\end{array}$ & $\begin{array}{c}1.59^{*} \\
(0.902)\end{array}$ & $\begin{array}{c}13.50 \\
(15.363)\end{array}$ & $\begin{array}{l}25.38^{* *} \\
(10.566)\end{array}$ & $\begin{array}{l}1.42^{* *} \\
(0.650)\end{array}$ & $\begin{array}{c}10.83 \\
(19.752) \\
\end{array}$ & $\begin{array}{c}0.66 \\
(5.863)\end{array}$ & $\begin{array}{c}-1.07 \\
(0.776)\end{array}$ \\
\hline Num of Obs. & 239 & 202 & 858 & 163 & 219 & 870 & 159 & 225 & 889 \\
\hline Pseudo $R^{2}$ & 0.163 & 0.175 & 0.149 & 0.0855 & 0.319 & 0.0735 & 0.390 & 0.269 & 0.0429 \\
\hline Cross-sec. FE & None & Region & Region & None & Region & Region & None & Region & Region \\
\hline Time-series FE & Decade & Decade & Decade & Decade & Decade & Decade & Decade & Decade & Decade \\
\hline
\end{tabular}


Table 4: Robustness: Banking crisis

This table presents the results for the robustness analysis. The dependent variable is a dummy variable that takes the value 1 in the first year of a banking crisis. In Columns I and II we use alternative definitions of high and low volatility. In Column I high and low volatility are defined as the deviation of volatility level from its historical mean calculated as the average volatility during the past ten years. In Column II, high and low volatility are defined as the deviation of volatility level from a one standard deviation band. In Column III volatility is calculated by employing monthly returns up to December (end year) instead of mid-year returns. In Column IV, we measure volatility as the sum of absolute monthly returns. We further examine the sensitivity of the results to the empirical methodology and chosen model specification. In Columns V and VI we repeat the analysis without any fixed effects and with country and year fixed effects. In Columns VII and VIII, we use three and seven, instead of five, years of backward-looking moving averages for the explanatory variables. In Column IX, we include the trend $(\tau)$ estimated through an HP filter in the regression along with high and low volatility variables. In Column X, we report the results when the smoothing parameter of the HP filter is set to 100 instead of 5000. In Column XI, we check whether our main results are still present if observations after 2008 and between 1914 and 1945 are excluded from the analysis. Finally, in Column XII, we report the results when we merge the crisis database of Reinhart and Rogoff (2009) with that of Bordo et al. (2001); Laeven and Valencia (2008); Gourinchas and Obstfeld (2012); Schularick and Taylor (2012). All of the variables introduced in Table 2 are included in all of the specifications. Similarly, time-series and cross-sectional fixed effects used in the regressions are listed in the last two rows. For the sake of brevity, the estimated coefficients of fixed effects and control variables are omitted.

The panel covers 60 countries and spans 1800-2010. The standard errors, reported in parentheses, are robust and clustered at the year level.

\begin{tabular}{|c|c|c|c|c|c|c|c|c|c|c|c|c|}
\hline Dep. Var. : $C_{i, t}^{\text {Banking }}$ & $\begin{array}{c}\text { Historical } \\
\text { Mean } \\
\text { I }\end{array}$ & $\begin{array}{c}\text { Band } \\
\text { II }\end{array}$ & $\begin{array}{l}12 \mathrm{M} \\
\mathrm{III}\end{array}$ & $\begin{array}{l}\text { ABS } \\
\text { IV }\end{array}$ & $\begin{array}{c}\text { No FEs } \\
\text { V }\end{array}$ & $\begin{array}{c}\text { Country-Year } \\
\text { FEs } \\
\text { VI }\end{array}$ & $\begin{array}{c}L=3 \\
\text { VII }\end{array}$ & $\begin{array}{l}L=7 \\
\text { VIII }\end{array}$ & $\begin{array}{c}\text { Trend } \\
\text { Included } \\
\text { IX }\end{array}$ & $\begin{array}{c}\lambda=100 \\
\mathrm{X}\end{array}$ & $\begin{array}{c}\text { Wars and } 2008 \\
\text { excluded } \\
\text { XI }\end{array}$ & $\begin{array}{l}\text { Merged } \\
\text { Data } \\
\text { XII }\end{array}$ \\
\hline$C_{i, t-1}$ to $t-5$ & $\begin{array}{c}-7.64^{* * *} \\
(2.298)\end{array}$ & $\begin{array}{c}-7.55^{* * *} \\
(2.286)\end{array}$ & $\begin{array}{c}-7.90^{* * *} \\
(1.855)\end{array}$ & $\begin{array}{c}-7.85^{* * *} \\
(1.916)\end{array}$ & $\begin{array}{l}-3.79^{* *} \\
(1.746)\end{array}$ & $\begin{array}{c}-8.62^{* * *} \\
(2.377)\end{array}$ & $\begin{array}{c}-5.30^{* * *} \\
(1.391)\end{array}$ & $\begin{array}{c}-9.19^{* * *} \\
(1.578)\end{array}$ & $\begin{array}{c}-7.86^{* * *} \\
(1.935)\end{array}$ & $\begin{array}{c}-7.62^{* * *} \\
(1.848)\end{array}$ & $\begin{array}{c}-8.62^{* * *} \\
(2.408)\end{array}$ & $\begin{array}{l}-6.53^{* * *} \\
(1.712)\end{array}$ \\
\hline$\delta_{i, t-1}^{\text {high }}$ to $t-5$ & $\begin{array}{l}0.18^{* *} \\
(0.078)\end{array}$ & $\begin{array}{l}0.24^{* *} \\
(0.107)\end{array}$ & $\begin{array}{c}0.08 \\
(0.116)\end{array}$ & $\begin{array}{c}0.21 \\
(0.137)\end{array}$ & $\begin{array}{c}0.15^{*} \\
(0.086)\end{array}$ & $\begin{array}{l}0.42^{* *} \\
(0.182)\end{array}$ & $\begin{array}{c}0.12 \\
(0.095)\end{array}$ & $\begin{array}{c}0.16 \\
(0.123)\end{array}$ & $\begin{array}{c}0.23^{*} \\
(0.128)\end{array}$ & $\begin{array}{c}0.04 \\
(0.179)\end{array}$ & $\begin{array}{l}0.29^{* *} \\
(0.146)\end{array}$ & $\begin{array}{l}0.12 \\
(0.113)\end{array}$ \\
\hline$\delta_{i, t-1}^{\text {low }}$ to $t-5$ & $\begin{array}{c}0.28^{* * *} \\
(0.107)\end{array}$ & $\begin{array}{l}0.48^{* *} \\
(0.194)\end{array}$ & $\begin{array}{l}0.21^{* *} \\
(0.084)\end{array}$ & $\begin{array}{c}0.35^{* * *} \\
(0.116)\end{array}$ & $\begin{array}{c}0.24^{* * *} \\
(0.075)\end{array}$ & $\begin{array}{l}0.42^{* *} \\
(0.173)\end{array}$ & $\begin{array}{l}0.23^{* * *} \\
(0.086)\end{array}$ & $\begin{array}{l}0.27^{* *} \\
(0.113)\end{array}$ & $\begin{array}{l}0.41^{* *} \\
(0.176)\end{array}$ & $\begin{array}{l}0.37^{* *} \\
(0.143)\end{array}$ & $\begin{array}{l}0.28^{* *} \\
(0.117)\end{array}$ & $\begin{array}{l}0.27^{* * *} \\
(0.102)\end{array}$ \\
\hline Num of Obs. & 1,968 & 1,965 & 2,181 & 2,134 & 2,886 & 1,111 & 2,108 & 2,152 & 2,134 & 2,134 & 1,677 & 2,134 \\
\hline Pseudo $R^{2}$ & 0.095 & 0.096 & 0.102 & 0.105 & 0.0292 & 0.231 & 0.0916 & 0.102 & 0.107 & 0.103 & 0.143 & 0.097 \\
\hline Cross-sec. FE & Region & Region & Region & Region & None & Country & Region & Region & Region & Region & Region & Region \\
\hline $\begin{array}{l}\text { Time-series FE } \\
\text { Control variables }\end{array}$ & $\begin{array}{c}\text { Decade } \\
\text { Yes }\end{array}$ & $\begin{array}{c}\text { Decade } \\
\text { Yes }\end{array}$ & $\begin{array}{c}\text { Decade } \\
\text { Yes }\end{array}$ & $\begin{array}{c}\text { Decade } \\
\text { Yes }\end{array}$ & $\begin{array}{l}\text { None } \\
\text { Yes }\end{array}$ & $\begin{array}{l}\text { Year } \\
\text { Yes }\end{array}$ & $\begin{array}{c}\text { Decade } \\
\text { Yes }\end{array}$ & $\begin{array}{l}\text { Decade } \\
\text { Yes }\end{array}$ & $\begin{array}{c}\text { Decade } \\
\text { Yes }\end{array}$ & $\begin{array}{l}\text { Decade } \\
\text { Yes }\end{array}$ & $\begin{array}{c}\text { Decade } \\
\text { Yes }\end{array}$ & $\begin{array}{l}\text { Decade } \\
\text { Yes }\end{array}$ \\
\hline
\end{tabular}


Table 5: Robustness: Stock market crises

This table presents the results for the robustness analysis. The dependent variable is a dummy variable that takes the value 1 in the first year of a stock market crisis. The robustness checks corresponding to each column are defined in Table 4 . All of the variables introduced in Table 2 are included in all of the specifications. Similarly, time-series and cross-sectional fixed effects used in the regressions are listed in the last two rows. For the sake of brevity, the estimated coefficients of fixed effects and control variables are omitted. The panel covers 60 countries and spans 1800-2010. The standard errors, reported in parentheses, are robust and clustered at the year level.

\begin{tabular}{|c|c|c|c|c|c|c|c|c|c|c|c|}
\hline Dep. Var. : $C_{i, t}^{\text {Banking }}$ & $\begin{array}{l}\text { Historical } \\
\text { Mean } \\
\text { I }\end{array}$ & $\begin{array}{c}\text { Band } \\
\text { II }\end{array}$ & $\begin{array}{c}12 \mathrm{M} \\
\mathrm{III}\end{array}$ & $\begin{array}{c}\text { ABS } \\
\text { VI }\end{array}$ & $\begin{array}{c}\text { No FEs } \\
\text { V }\end{array}$ & $\begin{array}{c}\text { Country-Year } \\
\text { FEs } \\
\text { VI }\end{array}$ & $\begin{array}{c}L=3 \\
\text { VII }\end{array}$ & $\begin{array}{l}L=7 \\
\text { VIII }\end{array}$ & $\begin{array}{c}\text { Trend } \\
\text { Included } \\
\text { IX }\end{array}$ & $\begin{array}{c}\lambda=100 \\
\mathrm{X}\end{array}$ & $\begin{array}{c}\text { Wars and } 2008 \\
\text { excluded } \\
\text { XI }\end{array}$ \\
\hline$C_{i, t-1}$ to $t-5$ & $\begin{array}{c}-4.90^{* * *} \\
(0.821)\end{array}$ & $\begin{array}{c}-4.87^{* * *} \\
(0.822)\end{array}$ & $\begin{array}{c}-4.88^{* * *} \\
(0.835)\end{array}$ & $\begin{array}{r}-4.96^{* * *} \\
(0.838)\end{array}$ & $\begin{array}{c}-4.26^{* * *} \\
(0.825)\end{array}$ & $\begin{array}{c}-5.89^{* * *} \\
(0.845)\end{array}$ & $\begin{array}{c}-3.73^{* * *} \\
(0.650)\end{array}$ & $\begin{array}{c}-5.64^{* * *} \\
(1.051)\end{array}$ & $\begin{array}{c}-4.86^{* * *} \\
(0.809)\end{array}$ & $\begin{array}{c}-5.03^{* * *} \\
(0.799)\end{array}$ & $\begin{array}{c}-3.92^{* * *} \\
(0.611)\end{array}$ \\
\hline$\delta_{i, t-1 \text { to } t-5}^{\text {high }}$ & $\begin{array}{l}0.14^{* *} \\
(0.059)\end{array}$ & $\begin{array}{l}0.18^{* *} \\
(0.083)\end{array}$ & $\begin{array}{c}0.17^{* * *} \\
(0.064)\end{array}$ & $\begin{array}{c}0.22^{* * *} \\
(0.076)\end{array}$ & $\begin{array}{c}0.22^{* * *} \\
(0.070)\end{array}$ & $\begin{array}{c}0.17^{*} \\
(0.090)\end{array}$ & $\begin{array}{c}0.16^{* * *} \\
(0.060)\end{array}$ & $\begin{array}{c}0.18^{*} \\
(0.103)\end{array}$ & $\begin{array}{c}0.19^{* * *} \\
(0.071)\end{array}$ & $\begin{array}{l}0.30^{* *} \\
(0.128)\end{array}$ & $\begin{array}{l}0.19^{* *} \\
(0.076)\end{array}$ \\
\hline$\delta_{i, t-1 \text { to } t-5}^{\text {low }}$ & $\begin{array}{l}0.19^{* *} \\
(0.089) \\
\end{array}$ & $\begin{array}{c}0.33^{* *} \\
(0.150) \\
\end{array}$ & $\begin{array}{c}0.12 \\
(0.081) \\
\end{array}$ & $\begin{array}{l}0.23^{* *} \\
(0.096) \\
\end{array}$ & $\begin{array}{c}0.25^{* * *} \\
(0.094) \\
\end{array}$ & $\begin{array}{l}0.21^{* *} \\
(0.100) \\
\end{array}$ & $\begin{array}{c}0.12 \\
(0.078) \\
\end{array}$ & $\begin{array}{c}0.22^{* * *} \\
(0.080) \\
\end{array}$ & $\begin{array}{c}0.33^{* * *} \\
(0.125)\end{array}$ & $\begin{array}{c}0.20^{*} \\
(0.111) \\
\end{array}$ & $\begin{array}{c}0.17^{*} \\
(0.092) \\
\end{array}$ \\
\hline Num of Obs. & 2,662 & 2,657 & 2,762 & 2,703 & 2,803 & 2,262 & 2,657 & 2,745 & 2,703 & 2,703 & 2,160 \\
\hline Pseudo $R^{2}$ & 0.065 & 0.066 & 0.0621 & 0.0640 & 0.0444 & 0.223 & 0.0619 & 0.0579 & 0.0650 & 0.0625 & 0.0502 \\
\hline Cross-sec. FE & Region & Region & Region & Region & None & Country & Region & Region & Region & Region & Region \\
\hline $\begin{array}{l}\text { Time-series FE } \\
\text { Control variables }\end{array}$ & $\begin{array}{c}\text { Decade } \\
\text { Yes }\end{array}$ & $\begin{array}{c}\text { Decade } \\
\text { Yes }\end{array}$ & $\begin{array}{c}\text { Decade } \\
\text { Yes }\end{array}$ & $\begin{array}{l}\text { Decade } \\
\text { Yes }\end{array}$ & $\begin{array}{l}\text { None } \\
\text { Yes }\end{array}$ & $\begin{array}{l}\text { Year } \\
\text { Yes }\end{array}$ & $\begin{array}{l}\text { Decade } \\
\text { Yes }\end{array}$ & $\begin{array}{l}\text { Decade } \\
\text { Yes }\end{array}$ & $\begin{array}{c}\text { Decade } \\
\text { Yes }\end{array}$ & $\begin{array}{c}\text { Decade } \\
\text { Yes }\end{array}$ & $\begin{array}{c}\text { Decade } \\
\text { Yes }\end{array}$ \\
\hline
\end{tabular}




\section{Table 6: Robustness: Currency crises}

This table presents the results for the robustness analysis. The dependent variable is a dummy variable that takes the value 1 in the first year of a currency crisis. The robustness checks corresponding to each column are defined in Table 4 . All of the variables introduced in Table 2 are included in all of the specifications. Similarly, time-series and cross-sectional fixed effects used in the regressions are listed in the last two rows. For the sake of brevity, the estimated coefficients of fixed effects and control variables are omitted. The panel covers 60 countries and spans 1800-2010. The standard errors, reported in parentheses, are robust and clustered at the year level.

\begin{tabular}{|c|c|c|c|c|c|c|c|c|c|c|c|c|}
\hline Dep. Var. : $C_{i, t}^{\text {Banking }}$ & $\begin{array}{c}\text { Historical } \\
\text { Mean } \\
\text { I }\end{array}$ & $\begin{array}{c}\text { Band } \\
\text { II }\end{array}$ & $\begin{array}{r}12 \mathrm{M} \\
\text { III }\end{array}$ & $\begin{array}{l}\text { ABS } \\
\text { VI }\end{array}$ & $\begin{array}{c}\text { No FEs } \\
\text { V }\end{array}$ & $\begin{array}{c}\text { Country-Year } \\
\text { FEs } \\
\text { VI }\end{array}$ & $\begin{array}{c}L=3 \\
\text { VII }\end{array}$ & $\begin{array}{l}L=7 \\
\text { VIII }\end{array}$ & $\begin{array}{c}\text { Trend } \\
\text { Included } \\
\text { IX }\end{array}$ & $\begin{array}{c}\lambda=100 \\
\mathrm{X}\end{array}$ & $\begin{array}{c}\text { Wars and } 2008 \\
\text { excluded } \\
\text { XI }\end{array}$ & $\begin{array}{l}\text { Merged } \\
\text { Data } \\
\text { XII } \\
\end{array}$ \\
\hline$C_{i, t-1}$ to $t-5$ & $\begin{array}{l}-1.48^{*} \\
(0.776)\end{array}$ & $\begin{array}{c}-1.61^{* *} \\
(0.778)\end{array}$ & $\begin{array}{c}-1.73^{* *} \\
(0.806)\end{array}$ & $\begin{array}{l}-1.91^{* *} \\
(0.815)\end{array}$ & $\begin{array}{c}-0.99 \\
(0.782)\end{array}$ & $\begin{array}{c}-2.58^{* * *} \\
(0.844)\end{array}$ & $\begin{array}{c}-1.54^{* * *} \\
(0.577)\end{array}$ & $\begin{array}{c}-1.48 \\
(0.936)\end{array}$ & $\begin{array}{c}-1.90 * * \\
(0.797)\end{array}$ & $\begin{array}{c}-1.89 * * \\
(0.811)\end{array}$ & $\begin{array}{c}-1.09 \\
(0.824)\end{array}$ & $\begin{array}{l}-2.08^{* *} \\
(0.847)\end{array}$ \\
\hline$\delta_{i, t-1 \text { to } t-5}^{\text {high }}$ & $\begin{array}{c}-0.01 \\
(0.062)\end{array}$ & $\begin{array}{c}-0.02 \\
(0.091)\end{array}$ & $\begin{array}{c}-0.04 \\
(0.086)\end{array}$ & $\begin{array}{c}-0.01 \\
(0.094)\end{array}$ & $\begin{array}{c}0.01 \\
(0.078)\end{array}$ & $\begin{array}{l}-0.08 \\
(0.121)\end{array}$ & $\begin{array}{c}0.01 \\
(0.073)\end{array}$ & $\begin{array}{c}0.10 \\
(0.088)\end{array}$ & $\begin{array}{l}-0.04 \\
(0.088)\end{array}$ & $\begin{array}{c}0.02 \\
(0.152)\end{array}$ & $\begin{array}{l}-0.04 \\
(0.114)\end{array}$ & $\begin{array}{l}-0.04 \\
(0.076)\end{array}$ \\
\hline$\delta_{i, t-1 \text { to } t-5}^{\text {low }}$ & $\begin{array}{c}0.03 \\
(0.067) \\
\end{array}$ & $\begin{array}{c}0.10 \\
(0.121) \\
\end{array}$ & $\begin{array}{c}0.04 \\
(0.059) \\
\end{array}$ & $\begin{array}{c}0.10^{*} \\
(0.059) \\
\end{array}$ & $\begin{array}{c}0.14^{* *} \\
(0.056) \\
\end{array}$ & $\begin{array}{c}-0.05 \\
(0.107) \\
\end{array}$ & $\begin{array}{c}0.05 \\
(0.055) \\
\end{array}$ & $\begin{array}{c}0.07 \\
(0.051) \\
\end{array}$ & $\begin{array}{c}0.05 \\
(0.107) \\
\end{array}$ & $\begin{array}{c}0.17^{*} \\
(0.091) \\
\end{array}$ & $\begin{array}{c}0.04 \\
(0.057) \\
\end{array}$ & $\begin{array}{l}0.02 \\
(0.047) \\
\end{array}$ \\
\hline Num of Obs. & 2,755 & 2,749 & 2,870 & 2,785 & 2,884 & 2,080 & 2,737 & 2,827 & 2,785 & 2,785 & 2,179 & 2,787 \\
\hline Pseudo $R^{2}$ & 0.027 & 0.027 & 0.0294 & 0.0316 & 0.00895 & 0.173 & 0.0316 & 0.0256 & 0.0311 & 0.0318 & 0.0351 & 0.040 \\
\hline Cross-sec. FE & Region & Region & Region & Region & None & Country & Region & Region & Region & Region & Region & Region \\
\hline $\begin{array}{l}\text { Time-series FE } \\
\text { Control variables }\end{array}$ & $\begin{array}{l}\text { Decade } \\
\text { Yes }\end{array}$ & $\begin{array}{c}\text { Decade } \\
\text { Yes }\end{array}$ & $\begin{array}{c}\text { Decade } \\
\text { Yes }\end{array}$ & $\begin{array}{c}\text { Decade } \\
\text { Yes }\end{array}$ & $\begin{array}{l}\text { None } \\
\text { Yes }\end{array}$ & $\begin{array}{l}\text { Year } \\
\text { Yes }\end{array}$ & $\begin{array}{c}\text { Decade } \\
\text { Yes }\end{array}$ & $\begin{array}{c}\text { Decade } \\
\text { Yes }\end{array}$ & $\begin{array}{c}\text { Decade } \\
\text { Yes }\end{array}$ & $\begin{array}{c}\text { Decade } \\
\text { Yes }\end{array}$ & $\begin{array}{c}\text { Decade } \\
\text { Yes }\end{array}$ & $\begin{array}{l}\text { Decade } \\
\text { Yes }\end{array}$ \\
\hline
\end{tabular}


Table 7: Risk-taking and the volatility channels

The table presents the results for the regression equations introduced in (6). For each specification, the dependent variable is listed in the column header. Credit-to-GDP ratio gap $\left(C R_{-} G A P_{i, t}\right)$ is the difference between the credit-to-GDP ratio and trend, estimated through an HP filtering with a smoothing parameter of 100. $\Delta \log C R_{i, t}$ is the difference of the log-credit-to-GDP ratio. In Columns I-IV credit data are obtained from BIS and GDP data from WDI and the panel covers 35 countries and spans 1960-2010. For the rest of the columns, data are obtained from Schularick and Taylor (2012) and cover 14 developed countries for 1870-2010. In Columns V-VIII credit is defined as total loans, whereas in Columns IX-XII it is defined as the total assets of the banking system. INTRATE is the real interest rate. The rest of the variables are introduced in Table 2. Past five year averages of the explanatory variables are used in the regressions. Region and decade fixed effects are included in all of the specifications. For the sake of brevity, the estimated coefficients of fixed effects are omitted. The standard errors, reported in parentheses, are robust and clustered at the year level.

\begin{tabular}{|c|c|c|c|c|c|c|c|c|c|c|c|c|}
\hline \multirow[t]{2}{*}{ Dep. Var. $\left(Y_{i, t}\right)$ : } & \multicolumn{2}{|c|}{$C R_{-} G A P_{i, t}^{\mathrm{BIS}}$} & \multicolumn{2}{|c|}{$\Delta \log C R_{i, t}^{\mathrm{BIS}}$} & \multicolumn{2}{|c|}{$C R \_G A P_{i, t}^{\text {STloans }}$} & \multicolumn{2}{|c|}{$\Delta \log C R_{i, t}^{\text {STloans }}$} & \multicolumn{2}{|c|}{$C R \_G A P_{i, t}^{\mathrm{STassets}}$} & \multicolumn{2}{|c|}{$\Delta \log C R_{i, t}^{\mathrm{STassets}}$} \\
\hline & I & II & III & IV & $\mathrm{V}$ & VI & VII & VIII & IX & $\mathrm{X}$ & $\mathrm{XI}$ & XII \\
\hline$\delta_{i, t-1 \text { to } t-5}^{\text {high }}$ & $\begin{array}{c}-1.72 \\
(1.404)\end{array}$ & $\begin{array}{c}-1.66 \\
(1.613)\end{array}$ & $\begin{array}{c}-0.16 \\
(0.403)\end{array}$ & $\begin{array}{c}-0.08 \\
(0.418)\end{array}$ & $\begin{array}{c}-0.77^{* * *} \\
(0.284)\end{array}$ & $\begin{array}{c}-0.95^{* * *} \\
(0.316)\end{array}$ & $\begin{array}{c}-0.54 \\
(0.582)\end{array}$ & $\begin{array}{c}-0.91 \\
(0.617)\end{array}$ & $\begin{array}{c}-1.16^{* *} \\
(0.465)\end{array}$ & $\begin{array}{c}-1.54^{* * *} \\
(0.505)\end{array}$ & $\begin{array}{c}-0.51 \\
(0.450)\end{array}$ & $\begin{array}{c}-0.67 \\
(0.527)\end{array}$ \\
\hline$\delta_{i, t-1}^{\text {low }}$ to $t-5$ & $\begin{array}{c}3.26^{* * *} \\
(0.880)\end{array}$ & $\begin{array}{c}3.56^{* * *} \\
(1.175)\end{array}$ & $\begin{array}{c}0.67^{*} \\
(0.334)\end{array}$ & $\begin{array}{l}0.77^{* *} \\
(0.364)\end{array}$ & $\begin{array}{c}0.71^{* *} \\
(0.304)\end{array}$ & $\begin{array}{c}0.86^{* *} \\
(0.339)\end{array}$ & $\begin{array}{l}1.24^{* * *} \\
(0.346)\end{array}$ & $\begin{array}{c}1.32^{* * *} \\
(0.458)\end{array}$ & $\begin{array}{c}1.78^{* * *} \\
(0.554)\end{array}$ & $\begin{array}{c}2.16^{* * *} \\
(0.618)\end{array}$ & $\begin{array}{l}1.07^{* * *} \\
(0.313)\end{array}$ & $\begin{array}{l}1.39^{* * *} \\
(0.434)\end{array}$ \\
\hline$Y_{i, t-1}$ to $t-5$ & $\begin{array}{c}0.40^{* * *} \\
(0.075)\end{array}$ & $\begin{array}{c}0.35^{* * *} \\
(0.075)\end{array}$ & $\begin{array}{l}0.11^{* *} \\
(0.049)\end{array}$ & $\begin{array}{c}0.06 \\
(0.085)\end{array}$ & $\begin{array}{c}0.47^{* * *} \\
(0.053)\end{array}$ & $\begin{array}{c}0.44^{* * *} \\
(0.061)\end{array}$ & $\begin{array}{c}0.19^{* * *} \\
(0.068)\end{array}$ & $\begin{array}{c}0.22^{* * *} \\
(0.076)\end{array}$ & $\begin{array}{c}0.37^{* * *} \\
(0.094)\end{array}$ & $\begin{array}{c}0.31^{* * *} \\
(0.106)\end{array}$ & $\begin{array}{c}0.21^{* * *} \\
(0.064)\end{array}$ & $\begin{array}{c}0.13 \\
(0.082)\end{array}$ \\
\hline $\log G D P_{i, t-1}$ to $t-5$ & & $\begin{array}{c}2.01 \\
(3.353)\end{array}$ & & $\begin{array}{c}-0.94 \\
(0.770)\end{array}$ & & $\begin{array}{c}-0.17 \\
(0.791)\end{array}$ & & $\begin{array}{c}-0.64 \\
(1.189)\end{array}$ & & $\begin{array}{c}1.49 \\
(1.020)\end{array}$ & & $\begin{array}{c}-0.50 \\
(1.091)\end{array}$ \\
\hline$\triangle P D / G D P_{i, t-1}$ to $t-5$ & & $\begin{array}{c}-1.92^{* * *} \\
(0.360)\end{array}$ & & $\begin{array}{c}-0.57^{* * *} \\
(0.138)\end{array}$ & & $\begin{array}{l}-0.07^{*} \\
(0.039)\end{array}$ & & $\begin{array}{c}-0.15 \\
(0.096)\end{array}$ & & $\begin{array}{c}-0.07 \\
(0.083)\end{array}$ & & $\begin{array}{c}-0.08 \\
(0.099)\end{array}$ \\
\hline$P O L C O M P_{i, t-1}$ to $t-5$ & & $\begin{array}{c}0.11 \\
(0.621)\end{array}$ & & $\begin{array}{c}0.17 \\
(0.146)\end{array}$ & & $\begin{array}{c}0.12^{*} \\
(0.069)\end{array}$ & & $\begin{array}{c}0.20 \\
(0.200)\end{array}$ & & $\begin{array}{c}0.16^{*} \\
(0.091)\end{array}$ & & $\begin{array}{c}0.08 \\
(0.171)\end{array}$ \\
\hline $\operatorname{INFLATION}_{i, t-1}$ to $t-5$ & & $\begin{array}{c}-0.22 \\
(0.335)\end{array}$ & & $\begin{array}{l}-0.23^{*} \\
(0.135)\end{array}$ & & $\begin{array}{c}0.37^{* * *} \\
(0.121)\end{array}$ & & $\begin{array}{c}0.66 \\
(0.481)\end{array}$ & & $\begin{array}{l}0.41^{* *} \\
(0.200)\end{array}$ & & $\begin{array}{c}0.30 \\
(0.264)\end{array}$ \\
\hline$I N T R A T E_{i, t-1}$ to $t-5$ & & $\begin{array}{c}-0.18 \\
(0.188)\end{array}$ & & $\begin{array}{c}0.00 \\
(0.043)\end{array}$ & & $\begin{array}{l}0.31^{* *} \\
(0.129)\end{array}$ & & $\begin{array}{c}0.56 \\
(0.482)\end{array}$ & & $\begin{array}{l}0.47^{* *} \\
(0.205)\end{array}$ & & $\begin{array}{c}0.35 \\
(0.246) \\
\end{array}$ \\
\hline Num of Obs. & 1,051 & 878 & 1,244 & 946 & 994 & 877 & 1,131 & 955 & 988 & 870 & 1,123 & 942 \\
\hline Adj. $R^{2} /$ Pseudo $R^{2}$ & 0.110 & 0.147 & 0.017 & 0.088 & 0.222 & 0.230 & 0.108 & 0.139 & 0.122 & 0.134 & 0.065 & 0.068 \\
\hline
\end{tabular}



and Political Science Houghton Street London WC2A 2AE United Kingdom

Tel: +44 (0)207405 7686 systemicrisk.ac.uk src@Ise.ac.uk 